\title{
Two new and two redescribed species of Anonchotaenia (Cestoda: Paruterinidae) from South American birds
}

\author{
Anna J. Phillips ${ }^{1}$, Boyko B. Georgiev ${ }^{2}$, Andrea Waeschenbach ${ }^{3}$ and Jean Mariaux ${ }^{4,5}$ \\ ${ }^{1}$ Department of Ecology and Evolutionary Biology, University of Connecticut, Storrs, CT, USA; \\ ${ }^{2}$ Institute of Biodiversity and Ecosystem Research, Bulgarian Academy of Sciences, Sofia, Bulgaria; \\ ${ }^{3}$ Department of Life Sciences, Natural History Museum, London, United Kingdom; \\ ${ }^{4}$ Natural History Museum of Geneva, Geneva, Switzerland; \\ ${ }^{5}$ Department of Genetics and Evolution, University of Geneva, Geneva, Switzerland
}

\begin{abstract}
Morphological examination of novel specimens of paruterinid cestodes from passerine birds from Brazil and Chile and of museum specimens from Paraguay revealed two new species: Anonchotaenia prolixa sp. n. from Elaenia albiceps chilensis Hellmayr from Chile, and Anonchotaenia vaslata sp. n. from Tyrannus melancholicus (Vieillot) (type host) and Myiodynastes maculatus (Statius Muller) from Paraguay. The generic diagnosis of Anonchotaenia Conn, 1900 is amended, prompted by the presence of the armed cirrus and the elongated cirrus sac of A. prolixa. Two species were redescribed: Anonchotaenia brasiliensis Fuhrmann, 1908 from Tachyphonus coronatus (Vieillot) and Thraupis cyanoptera (Vieillot) (new host records) from Brazil, and Thraupis sayaca (Linnaeus) and Volatinia jacarina (Linnaeus) from Paraguay (new host and geographic records); and Anonchotaenia macrocephala Fuhrmann, 1908 from Tachycineta leucorrhoa (Vieillot) (new host record) from Brazil, Tachycineta meyeni (Cabanis) from Chile (new host and geographic record) and Stelgidopteryx ruficollis (Vieillot) from Paraguay (new host and geographic record). Scanning electron microscopy of $A$. brasiliensis and A. macrocephala revealed less microthrix variation than has been reported for other cyclophyllidean taxa. Sequence data were generated for nuclear $s s r$ - and $l s r$-DNA and mitochondrial $r r n L$ and $\operatorname{cox} 1$ for $A$. prolixa, A. brasiliensis, and A. macrocephala. Maximum likelihood and Bayesian inference analyses supported each species as distinct, but revealed cryptic diversity among $A$. brasiliensis specimens from different host families. New host records of $A$. brasiliensis and A. macrocephala prompted a formal assessment of host specificity. Anonchotaenia prolixa was found to be oioxenous $\left(\mathrm{HS}_{\mathrm{S}}=0\right)$, A. vaslata and A. macrocephala were found to be metastenoxenous $\left(\mathrm{HS}_{\mathrm{S}}=3.000\right.$ and 3.302 , respectively), whereas $A$. brasiliensis was found to be euryxenous $\left(\mathrm{HS}_{\mathrm{S}}=5.876\right)$. Anonchotaenia brasiliensis has been found parasitising several species of different passerine families that participate in mixed-species foraging flocks in the Atlantic Forest. A diversity of species of other families join these flocks and are among the substantial number of South American passerine species yet to be examined for cestodes.
\end{abstract}

Keywords: Anonchotaenia prolixa, Anonchotaenia vaslata, Anonchotaenia brasiliensis, Anonchotaenia macrocephala, new species, new host record, Brazil, Chile, Paraguay, new geographical record

This article contains supporting information (Table S1, S2) online at http://folia.paru.cas.cz/suppl/2014-5-441.pdf

Anonchotaenia Cohn, 1900 is one of 22 genera of Paruterinidae that is characterised by an unarmed scolex, short, wide proglottides, vermiform oncospheres and a uterus without septa (Georgiev and Kornyushin 1994, Phillips et al. 2012). It contains 27 species that parasitise a wide diversity of passeriform hosts and has a cosmopolitan distribution (Voge and Davis 1953, Dollfus 1959, Singal 1963, Ulmer and James 1976, Olsen et al. 1978, Shinde 1984, Schmidt 1986, Sharma and Mathur 1987, Mariaux 1991). The latest contributions to the systematics of Anonchotaenia include erection of the subgenus Anonchotaenia (Paranonchotaenia) Mariaux, 1991 and the description of two new species from the Ivory Coast (Mariaux 1991). Most recently, sperm ultrastructure and spermiogenesis was characterised in Anonchotaenia globata (von Linstow, 1879) by Yoneva et al. (2010). Species delimitation within Anonchotaenia is challenging because the few available morphological characters are easily obscured or distorted in contracted material. Testis number per proglottis historically has been considered the most reliable character for delimiting species of Anonchotaenia, although this character is known to vary between conspecifics and even within an individual's strobila (Mariaux 1991). The addition of molecular data to phylogenetic analyses has been 
suggested to clarify species boundaries within the genus (Mariaux 1991).

South American Anonchotaenia species are poorly known, with only six species in total reported from the continent and all but two of these species described with brief treatments prior to 1909 (Fuhrmann 1901, 1908). As part of the present study, fieldwork conducted near the Comau Fjord, Chile in 2008 and near São Paulo, Brazil in 2011 led to the collection of cestode specimens from a diversity of avian orders, but predominantly Passeriformes. Examination of this material combined with the study of museum specimens resulted in the description of two new species of Anonchotaenia as well as the redescription of Anonchotaenia brasiliensis Fuhrmann, 1908 and Anonchotaenia macrocephala Fuhrmann, 1908. Anonchotaenia brasiliensis and A. macrocephala are the first paruterinid taxa to be examined with scanning electron microscopy (SEM). Sequences from the newly collected specimens are some of the first molecular sequences of paruterinids and were the basis for phylogenetic analyses. Host specificity had not been previously measured for members of Paruterinidae prompting the first formal assessment of host specificity for the family to assess trends of host spectrum breadth, overlap of host spectrum and host specificity in comparison to other cestode groups.

\section{MATERIALS AND METHODS}

\section{Specimen sampling and abbreviations}

Cestodes studied included newly collected material from Brazil and Chile, which were obtained as part of a collaborative effort focused on a global assessment of cestode diversity funded by the National Science Foundation (NSF) Planetary Biodiversity Inventory (PBI) project 'A Survey of the Tapeworms (Cestoda: Platyhelminthes) from Vertebrate Bowels of the Earth' (NSF PBI award Nos. 0818696 and 0818823). In Brazil, birds were sampled at two localities. At Estação Biológica de Boracéia, Salesópolis, São Paulo, Brazil $\left(23^{\circ} 38^{\prime} \mathrm{S}\right.$; $45^{\circ} 52^{\prime} \mathrm{W}$, elevation $946 \mathrm{~m}$ ) during 24-28 November 2011, 164 adult birds, including 46 passerine species and one species each from Columbiformes, Piciformes and Trogoniformes, were captured by mist netting in semi-deciduous forest. At Fazenda Nabor, Tremembé, São Paulo, Brazil $\left(22^{\circ} 55.45^{\prime} \mathrm{S} ; 4^{\circ} 34.25^{\prime} \mathrm{W}\right.$, elevation $540 \mathrm{~m}$ ) during 30 November-3 December 2011, 47 adult birds, including 14 species of Passeriformes, six of Pelecaniformes, three of Cuculiformes, two of Accipitriformes, two of Columbiformes, two of Piciformes and one species each of Charadriiformes, Anseriformes, Psittaciformes and Strigiformes, were collected by shooting in rice fields and surrounding shrublands.

At both localities, bird specimens were identified by skilled ornithologists. Bird specimens collected at Estação Biológica de Boracéia were deposited at the Museu de Zoologia Universidade de São Paulo, São Paulo, Brazil and bird specimens collected from Fazenda Nabor were deposited at the Museu Nacional Rio de Janeiro, Brazil. In Chile, 87 birds, including 19 species from 15 families were captured by mist netting and shooting at Huinay Station, Comau Fjord, Los Lagos Region, Chile (42²2'47"S; 72²2'54"W, elevation ca 20 m). Avian no- menclature follows the IOC World Bird Names (Gill and Donsker 2012).

Museum abbreviations used here are: MHNG-PLAT - Natural History Museum of Geneva, Geneva, Switzerland; MZUSP - Museu de Zoologia Universidade de São Paulo, São Paulo, Brazil; MNRJ - Museu Nacional Rio de Janeiro, Brazil; UFRJ - Universidade Federal do Rio de Janeiro, Brazil; USNPC - United States National Parasite Collection, Smithsonian's National Museum of'Natural History, Washington, D.C.. Specimens collected through the PBI project are indicated by the number assigned specimens (PBI- $)$ and are listed in the Global Cestode Database (tapewormdb.uconn.edu). Collectors' authorities for specimens obtained during the Expédition du Muséum de Genève au Paraguay are given as EMGP.

\section{Specimen preparation and morphological examination}

Newly collected cestodes underwent different preparations: a subset of worms had the two to three most terminal proglottides removed and fixed in $95 \%$ ethanol for molecular work and the remaining complete worms and fragments were fixed in hot $5 \%$ formalin and subsequently transferred to $70 \%$ ethanol for storage. For light microscopy, a subset of worms were stained with hydrochloric carmine, dehydrated in an ascending ethanol series, cleared in methyl-salicylate, and mounted in Canada balsam for morphological examination.

Measurements were taken using an optical retical on a Nikon Eclipse 80i microscope. Measurements are given in micrometres $(\mu \mathrm{m})$ unless otherwise stated. Measurements of the testes, cirrus sac, vitellarium and ovary were taken only from fully developed mature and early pregravid proglottides. Extent of the cirrus sac is reported as the percentage the cirrus sac that extends across the proglottis width. Metrical and meristic data are presented as the range, followed by the mean, standard deviation and the number of measurements or counts taken (n) in parentheses. Illustrations were made with the aid of a drawing tube and Adobe Illustrator ${ }^{\circledR}$ and Adobe Photoshop ${ }^{\circledR}$. The terms used for the developmental stages of proglottides follow Georgiev and Vaucher (2001).

Scoleces of worms from Tachyphonus coronatus (Vieillot), Tachycineta leucorrhoa (Vieillot), Thraupis cyanoptera (Vieillot) and Ammodramus humeralis (Bosc) collected in Brazil in 2011 were prepared for SEM with the following procedure: they were hydrated in a graded filtered ethanol series, post-fixed in $1.5 \%$ osmium tetroxide overnight, washed in distilled water, dehydrated in a graded filtered ethanol series, transferred to hexamethyldisilizane (Ted Pella, Inc., Redding, CA, USA) and allowed to air dry in a fume hood. The specimens were then mounted on aluminium stubs on double-sided adhesive carbon tabs (Ted Pella, Inc.). Specimens were sputter-coated with ca $35 \mathrm{~nm}$ of gold/palladium and examined with a LEO/Zeiss DSM982 (Zeiss, Oberkochen, Germany) digital field emission scanning electron microscope at the Electron Microscopy Laboratory at the University of Connecticut, Storrs, CT, USA. Scoleces examined with SEM were retained in the personal collection of Janine N. Caira (University of Connecticut).

During the present study, several specimens from passerine hosts in South America were determined to represent Anonchotaenia but could not be definitively identified to species (Table S1). These specimens have been included here because they represent new host records and additional diversity of Anonchotaenia. 


\section{Generation of nucleotide data}

Sequence data for almost complete small subunit nuclear ribosomal RNA gene (ssrDNA) (=18S rDNA), domains D1-D3 of large subunit nuclear ribosomal RNA gene (lsrDNA) (= 28S rDNA), partial large mitochondrial ribosomal RNA subunit $(r r n L)(=16 \mathrm{~S}$ rDNA) and partial cytochrome $c$ oxidase subunit I ( $\operatorname{cox} 1)$ were generated de novo for newly collected cestode specimens, i.e. two outgroup taxa and six Anonchotaenia representatives (GenBank accession numbers: KF685910 KF685939; Table S2). Tissue samples for DNA extraction consisted of two or three of the most terminal proglottides or a subset from the middle of the strobila of complete worms, while the scolex and remaining strobila of each worm were prepared as whole mounts as previously described. Voucher specimens were deposited in the MZUSP, MHNG and the USNPC. For details of genomic DNA extraction, PCR, sequencing, sequence editing and sequence identity verification, see Scholz et al. (2013).

\section{Phylogenetic analyses}

Outgroup selection consisted of Biuterina sp. (PBI-96 from host PBI-GAB-106 Andropadus latirostris Strickland from Franceville, Haut Ogooue, Gabon, $1^{\circ} 36^{\prime} 57^{\prime \prime S}$; 1334'55"E) and Dictyterina cholodkowskii (Skrjabin, 1914) (PBI-173 from host PBI-CHIN-049 Lanius tephronotus (Vigors) from Yuzhong,

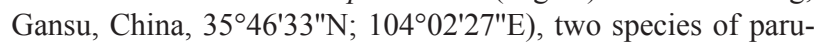
terinid genera that are characterised by the possession of hooks and therefore easily distinguished morphologically from the taxa of interest in this study and formed part of the sister group to the ingroup in a wider analysis of Cyclophyllidea of currently unpublished data.

Sequences were aligned using MAFFT v. $6.611 \mathrm{~b}$ (Katoh et al. 2005) with 1000 cycles of iterative refinement and the genafpair algorithm. The alignment was improved by eye using MacClade (Maddison and Maddison 2005). Positions that could not be unambiguously aligned were excluded from any subsequent analyses. Modeltest v. 3.7macX (Posada and Crandall 1998) was used to select models of evolution using the Akaike Information Criterion. Phylogenetic analyses were conducted using two approaches: Maximum likelihood (ML) and Bayesian inference (BI). Bayesian Inference trees were constructed using MrBayes v. 3.2.1 (Huelsenbeck and Ronquist 2001). Likelihood settings for $\operatorname{ss} D N A$ and $l s r D N A$ were set to nst $=6$, rates $=i n v$, and for $r r n L$ and $\operatorname{cox} 1$ were set to $n s t=6$, rates $=$ gamma, equivalent to the GTR $+\mathrm{I}$ and GTR $+\mathrm{G}$ models, respectively. Parameters were estimated separately for each partition. Four chains (heated chains temp $=0.2$ ) were run for 5000000 generations and sampled every 1000 generations. A total of 500000 generations were discarded as burn-in, at which point the average standard deviation of split frequencies was $<0.01$. The frequency with which a particular clade was present in the posterior distribution is represented by the clade's posterior probability ( $\mathrm{pp}$ ).

Maximum likelihood analyses were performed in PAUP* v. 4 b10 (Swofford 2003) using successive approximation: model parameters were estimated based on a starting tree determined by neighbour-joining. A heuristic search was performed implementing the estimated model parameters using nearest-neighbourinterchange branch swapping. Model parameters were estimated on the best tree and a heuristic search performed using subtreepruning-regrafting branch swapping implementing the estimated model parameters. After estimating model parameters, heuristic searches using tree-bisection-reconnection branch swapping were performed until the topology remained unchanged. Un- corrected ' $\mathrm{p}$ ' distances were calculated for $r r n L$ and cox 1 gene fragments using Geneious Pro v. 5.6.4 created by Biomatters and available at http://www.geneious.com.

\section{Measurement of host specificity}

Host specificity at the species level was assessed using the Index of Phylogenetic Host Specificity (Caira et al. 2003) and standardised terminology for categories of host specificity proposed by Caira et al. (2003) was followed.

\section{RESULTS}

\section{Paruterinidae Fuhrmann, 1907}

Genus Anonchotaenia Cohn, 1900

Anonchotaenia (Paranonchotaenia) prolixa sp. n.

Figs. 1A, 2

Description (based on one complete worm and one fragment of strobila): Body ribbon-like, up to $28 \mathrm{~mm}$ $(n=1)$. Maximum width $700(n=2)$, at level of early gravid proglottides (Fig. 1A). Mature proglottides acraspedote, 4 to 8 times wider than long; pregravid and gravid proglottides slightly craspedote, as wide as long. Scolex rounded, $565(\mathrm{n}=1)$ in diameter, with 4 muscular suckers, 225-250 $(240 \pm 12, n=4)$ in diameter (Fig. 3A). First proglottides appear $0.78 \mathrm{~mm}(\mathrm{n}=1)$ from posterior margin of suckers. Mature proglottides appear $3.74 \mathrm{~mm}(\mathrm{n}=1)$ posterior to appearance of first proglottides (Fig. 1A). Genital pores irregularly alternating in short series (e.g. 2, 1, 2, 2, 1, 1, $2,1,2,2,1,1, \ldots)$, opening equatorial along lateral edge of proglottis. Genital atrium with infundibular orifice, pyriform, narrow, deep. Genital ducts pass between osmoregulatory canals. Osmoregulatory canals classically disposed; dorsal osmoregulatory canals 7.5-22 (12 \pm 7 , $\mathrm{n}=4$ ) in diameter; ventral osmoregulatory canals 20-50 $(32 \pm 13, \mathrm{n}=4)$ in diameter, with transverse anastomoses along posterior margin of each proglottis.

Testes spherical, slightly oval to oval in contracted proglottides, 4-6 [4 (14\%), $5(66 \%), 6(20 \%)](5 \pm 0.6$, $\mathrm{n}=59)$ in number, $28-58(47 \pm 10, \mathrm{n}=10)$ long, $40-53$ ( $48 \pm 4, \mathrm{n}=10$ ) wide; arranged in single transverse dorsal row, occasionally overlapping osmoregulatory canals (Fig. 2B), persist in pregravid proglottides. Cirrus sac very large, claviform, thick-walled, muscular (Fig. 2C); 172-225 (192 $\pm 14, \mathrm{n}=31)$ long and 38-60 (47 \pm 6 , $\mathrm{n}=31)$ wide in mature proglottides, 245-270 (255 \pm 12 , $\mathrm{n}=5)$ long and 55-62.5 (59 $\pm 3, \mathrm{n}=5)$ wide in postmature or early pregravid proglottides; crossing and surpassing osmoregulatory canals, reaching over one third of proglottis width, length extending 30-40\% (36 $\pm 3 \%$, $\mathrm{n}=10)$ across width of proglottis. Cirrus cylindrical, finely and densely armed on its entire length with small spines approximately 3 in length, occasionally straight but usually with one or two loops at mid-length when invaginated (Fig. 2E). Internal vas deferens thin, making a few loops in proximal part of cirrus sac. External vas deferens coiled, ventral to cirrus sac. 


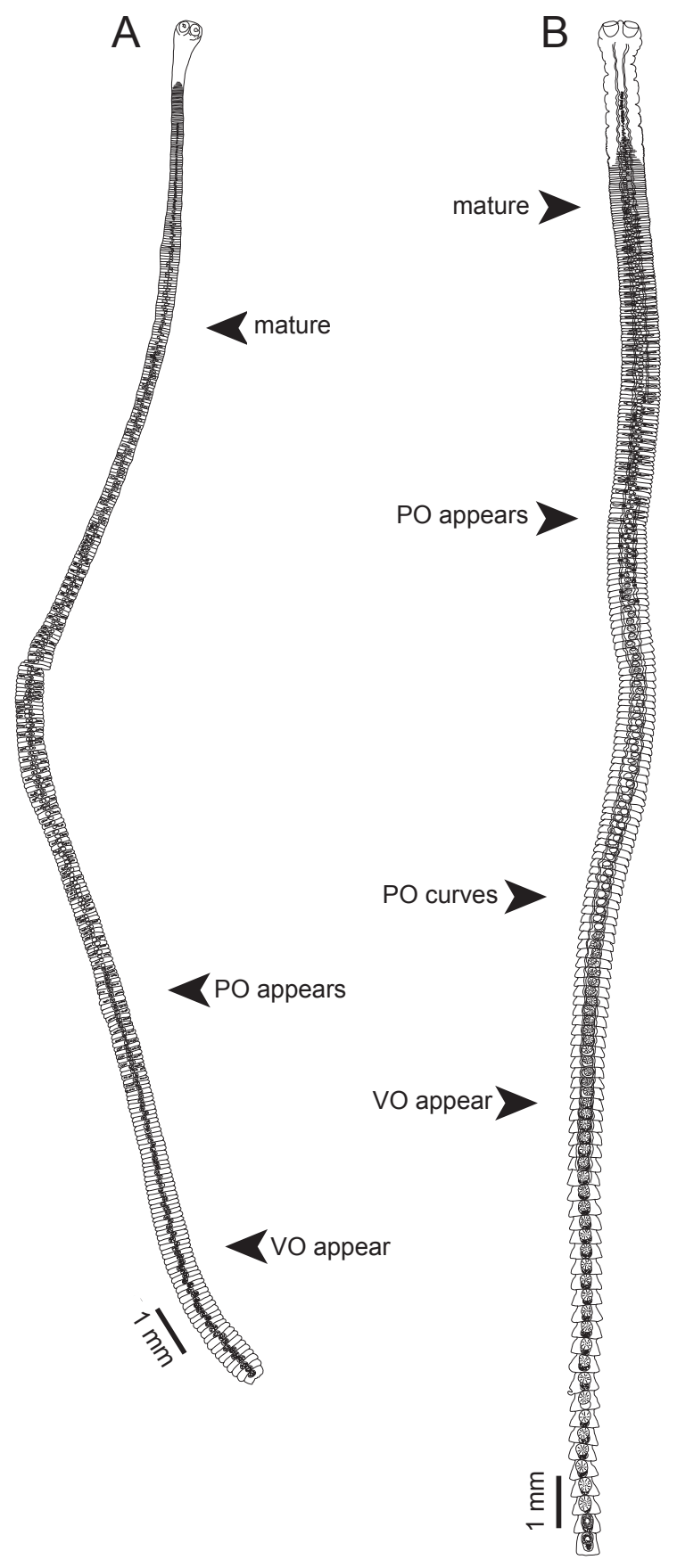

Fig. 1. Drawings of whole worms. A - Anonchotaenia prolixa sp. n., holotype (MHNG-PLAT-64401), from Elaenia albiceps chilensis; B - Anonchotaenia vaslata sp. n., holotype (MHNGPLAT 37770), from Tyrannus melancholicus. Abbreviations: $\mathrm{PO}$ - paruterine organ; $\mathrm{VO}$ - vermiform oncospheres.

Ovary oval, medial, 65-95 (79 $\pm 9, \mathrm{n}=10)$ long, $58-103(85 \pm 13, \mathrm{n}=10)$. Vitellarium compact, round, $48-65(57 \pm 6, \mathrm{n}=10)$ long, 50-70 $(59 \pm 5, \mathrm{n}=10)$, aporal to ovary. Mehlis' gland indistinct. Seminal receptacle fusiform, not clearly distinct from vagina. Vagina conspicuous, walls well-demarcated (Fig. 2C), opening posterior to male pore. Copulatory portion wide in mature proglottides (Fig. 2B), decreasing in width in pregravid proglottides (Fig. 2D,F), tapering to conductive portion, passing posterior and parallel to cirrus sac, rarely crossing. Conductive portion making one or two very big loops along aporal end of cirrus sac.

Uterus circular to oval, sac-like, dorsal to ovary in postmature and early pregravid proglottides, expanding to fill median field, usually not overlapping cirrus sac in pregravid proglottides (Fig. 2D,F). Uterine wall thickening as proglottis matures. Paruterine organ pyramidal, consisting of uniform fibrilar tissue, developing as thickening of anterior uterine wall, directed anteroporally to uterus, appearing approximately 150-163 proglottides posterior to first mature proglottides (Fig. 1A). Eggs initially spherical. Oncospheres and embryophore transform into vermiform shape in pregravid proglottides approximately 40-42 proglottides posterior to appearance of paruterine organ (Fig. 1A), gradually filling uterus, eggs passing into paruterine cavity not observed (Fig. 2F). Embryonic hooks not observed.

Type and only host: Elaenia albiceps chilensis Hellmayr, white-crested elaenia (Passeriformes: Tyrannidae).

Type and only locality: Huinay Station, Comau Fjord, Los Lagos Region, Chile (42²2'47"S; 72²2'54"W, $21 \mathrm{~m})$.

Site of infection: Small intestine.

Prevalence and intensity of infection: $8.3 \%$ ( 1 host infected of 12 examined), 2 worms.

Type specimens: Holotype (MHNG-PLAT-64401); 1 paratype (MHNG-PLAT-64403).

E t y molog y: prolixa $($ Latin $)=$ extended or elongated; referring to the unusually long cirrus sac.

Remarks. Anonchotaenia (Paranonchotaenia) prolixa sp. n. is unique from the other 27 species of Anonchotaenia (Table 1) in the possession of an armed cirrus and a cirrus sac that extends into the median field of the proglottis. The new species has genital ducts that pass between the osmoregulatory canals as in members of the subgenus Anonchotaenia (Paranonchotaenia), including Anonchotaenia malaconoti Mariaux, 1991, Anonchotaenia prionopos Mariaux, 1991 and Anonchotaenia dendrocitta (Woodland, 1929). Anonchotaenia prolixa sp. n. is unique from the Anonchotaenia species that possess fewer than 7 testes and for which the subgeneric position is unclear (Table 1): Anonchotaenia prolixa sp. n. possesses larger suckers $(225-250 \mu \mathrm{m})$ than Anonchotaenia mexicana Voge et Davis, 1953 (121-198 $\mu \mathrm{m})$, Anonchotaenia ranae (Ulmer et James, 1976) (138-175 $\mu \mathrm{m})$ and Anonchotaenia zonotrichicola Dollfus, 1959 (170-200 $\mu \mathrm{m})$, possesses a smaller scolex (565 $\mu \mathrm{m}$ in diameter) than Anonchotaenia sbesteriometra Joyeux et Baer, 1935 $(740 \mu \mathrm{m})$, and a larger cirrus sac $(172-225 \times 38-60 \mu \mathrm{m})$ than A. zonotrichicola $(46-54 \times 22 \mu \mathrm{m})$ and Anonchotaenia zanthopygiae Yamaguti, $1956(60-100 \times 18-22 \mu \mathrm{m})$. 
A

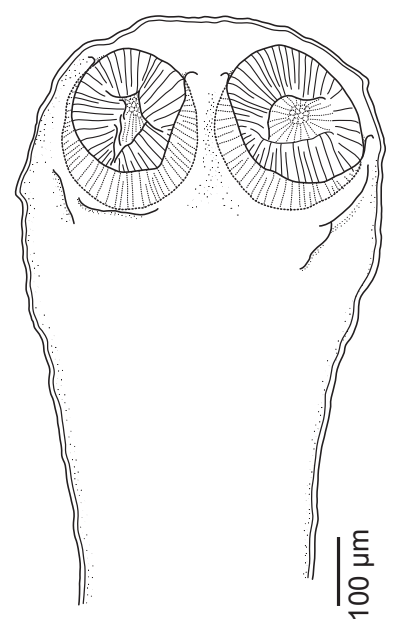

C

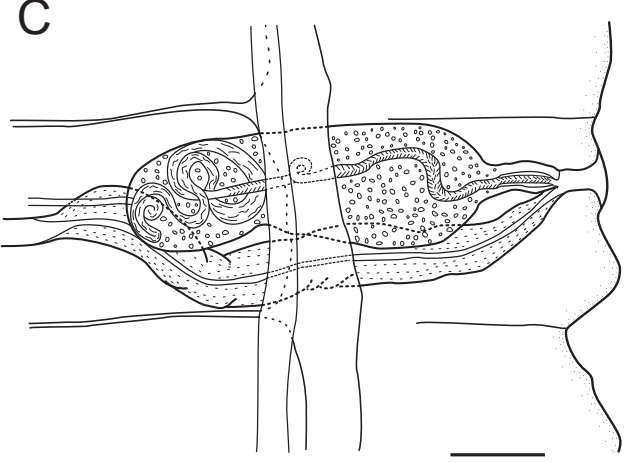

$50 \mu \mathrm{m}$

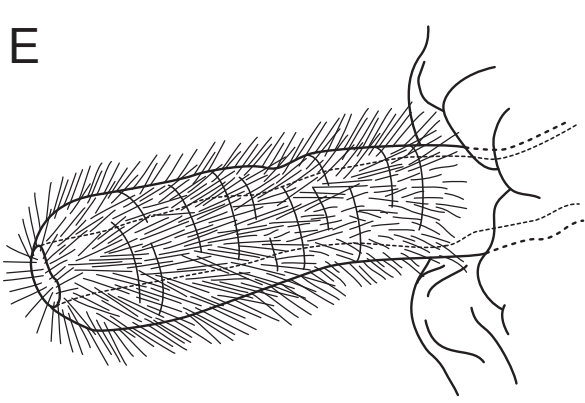

$\overline{10 \mu \mathrm{m}}$
D

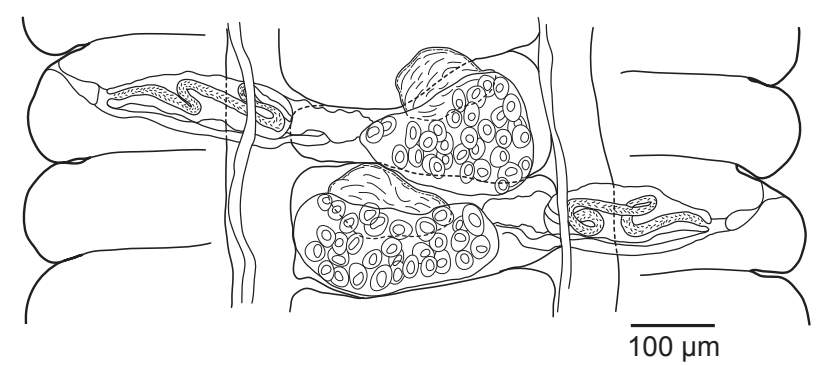

B

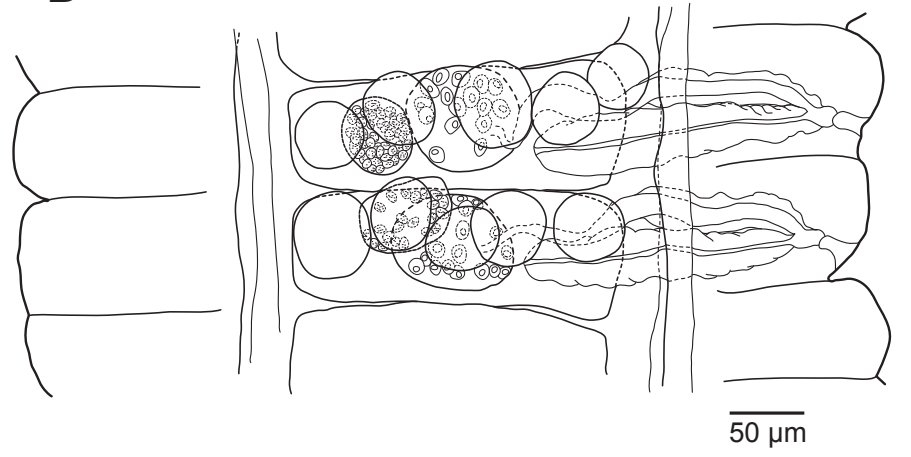

$\mathrm{F}$

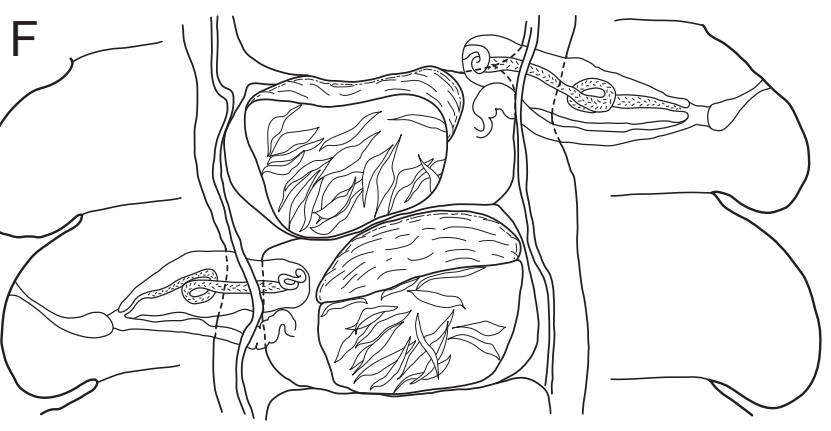

$\overline{100 \mu \mathrm{m}}$

Fig. 2. Anonchotaenia prolixa sp. n., holotype (MHNG-PLAT-64401), from Elaenia albiceps chilensis. A - scolex; B - mature proglottides; $\mathbf{C}$ - terminal genital ducts; $\mathbf{D}$ - early pre-gravid proglottides; $\mathbf{E}$ - everted armed cirrus; $\mathbf{F}$ - late pre-gravid proglottides.

In light of the unique characters of A. prolixa sp. n., i.e. the possession of an armed cirrus and a cirrus sac that extends into the median field of the proglottis that differentiates this species from its congeners, the generic diagnosis proposed by Georgiev and Kornyushin (1994) was amended (as follows):

\section{Genus Anonchotaenia Cohn, 1900}

Amended diagnosis: Scolex without rostellum or rostellar hooks. Suckers muscular, deep. Mature proglottides considerably wider than long (seven to ten times or more), acraspedote; gravid proglottides with almost equal length and width, craspedote. Genital pores alternating. Genital ducts ventral to or between osmoregulatory canals.
Testes occupying all median field. Cirrus sac may reach osmoregulatory canals or cross into median field. Cirrus unarmed or exceptionally armed. Vitellarium compact, round, slightly poral, median or slightly aporal. Ovary compact, oval, poral. Seminal receptacle round or slightly oval, near point where osmoregulatory canals and genital ducts cross. Uterus spherical or oval. Developing paruterine organ aporal and dorsal to uterus; paruterine organ anterior to uterus in last gravid proglottides. Eggs with vermiform oncospheres. In Passeriformes (different families), sometimes (probably accidentally) in Apodiformes (Apodidae, Trochilidae), Ciconiiformes (Threskiornithidae) and amphibians. Cosmopolitan. 


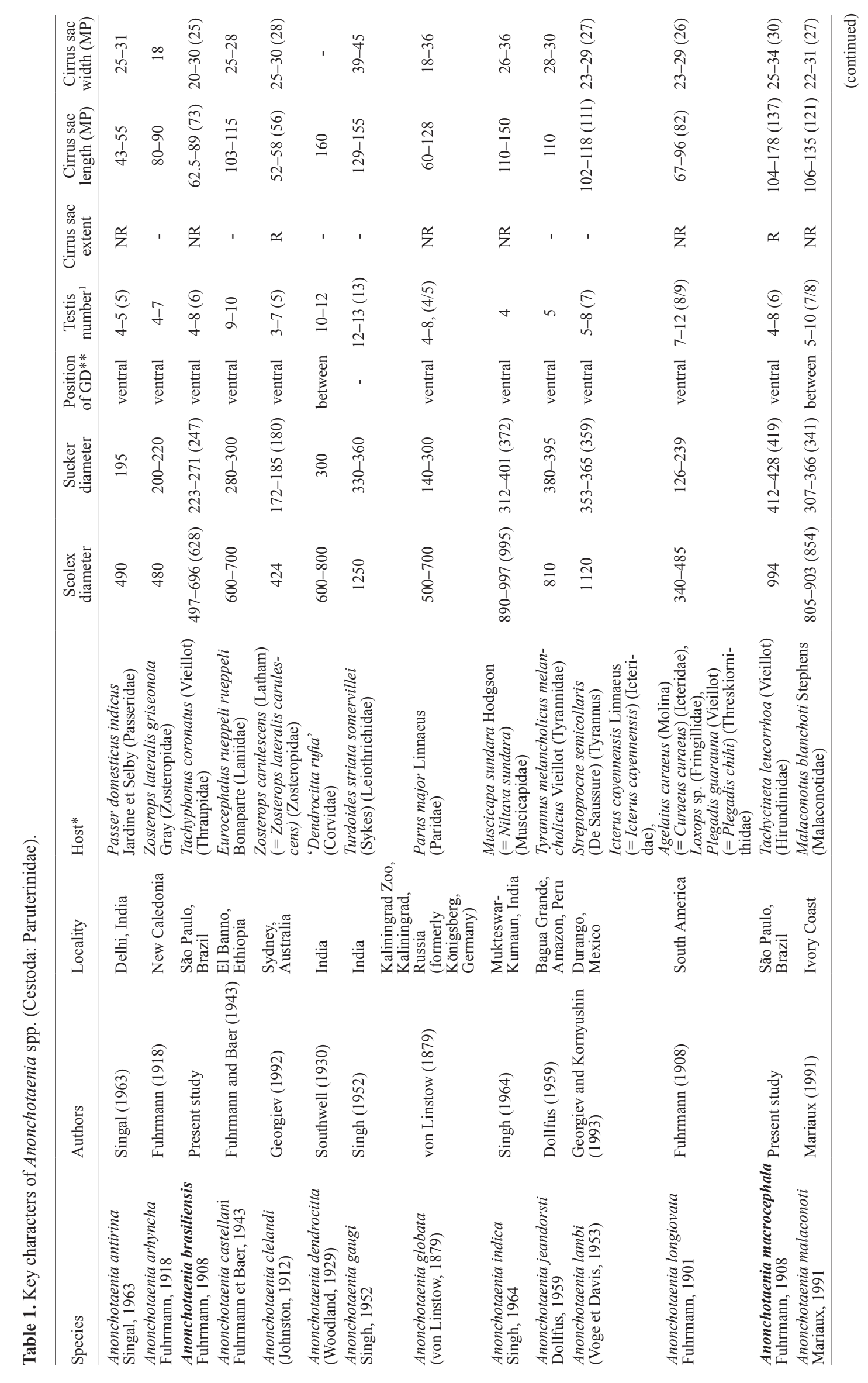


Phillips et al.: Anonchotaenia spp. from South American birds

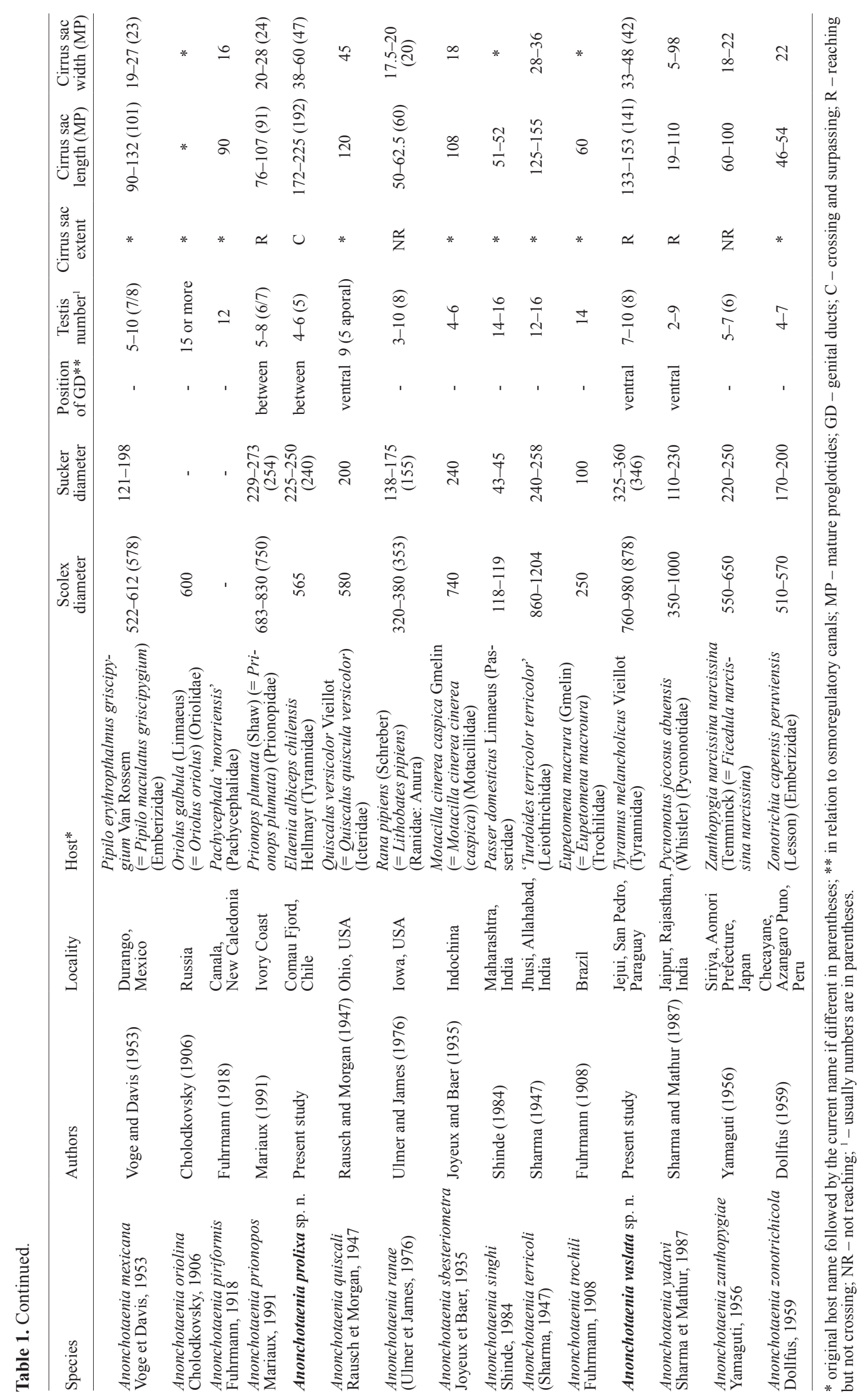




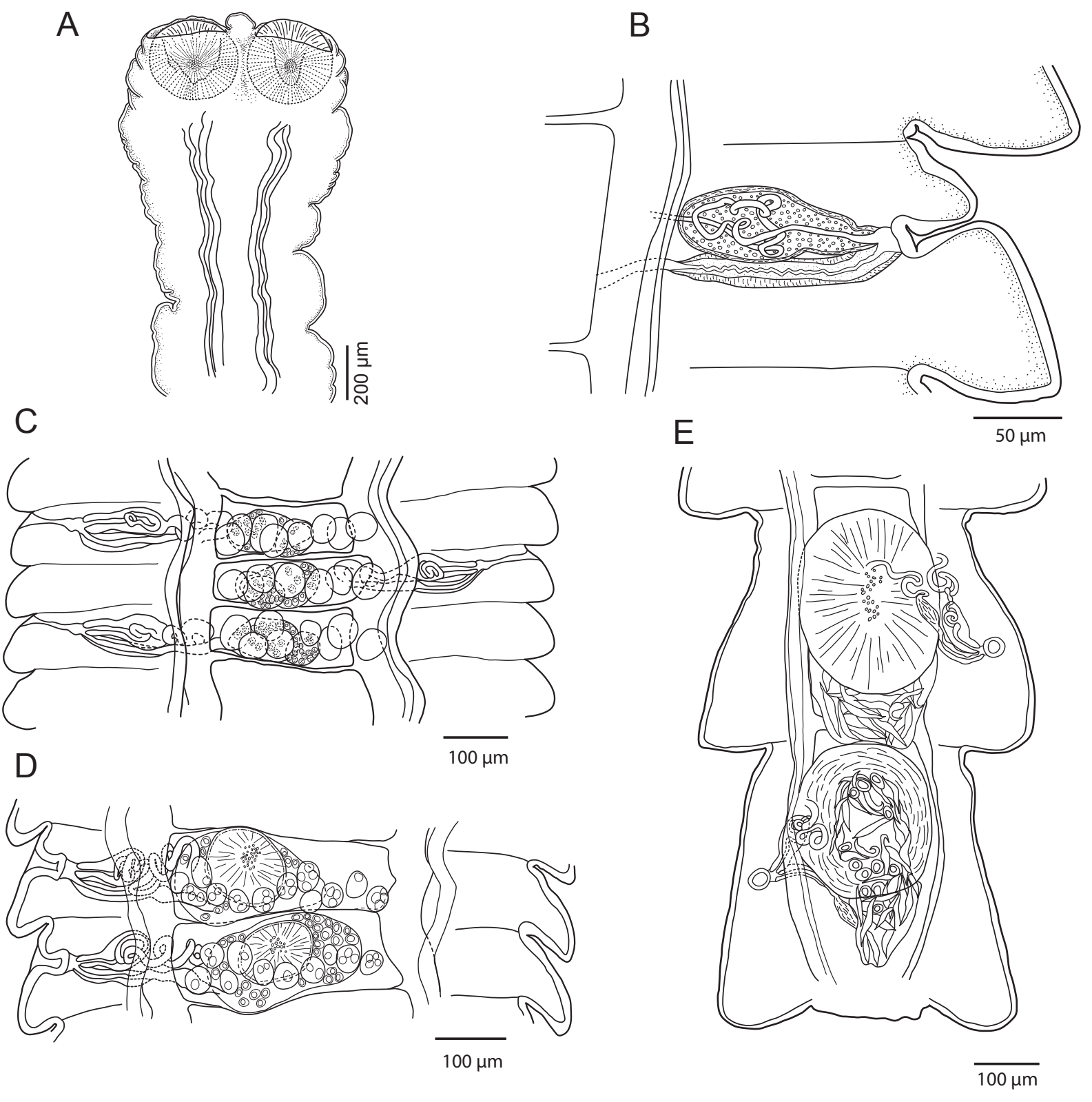

Fig. 3. Anonchotaenia vaslata sp. n., holotype (MHNG-PLAT 37770), from Tyrannus melancholicus. A - scolex; B - terminal genital ducts; $\mathbf{C}$ - mature proglottides; $\mathbf{D}$ - pre-gravid proglottides; $\mathbf{E}$ - gravid proglottides with eggs passing into the paruterine organ.

Type species: Anonchotaenia clava Cohn, 1900, a junior synonym of $A$. globata (von Listow, 1879).

Other species: See Table 1 for the list and key measurements of valid Anonchotaenia spp.

\section{Anonchotaenia (Anonchotaenia) vaslata sp. n.}

Figs. $1 \mathrm{~B}$ and 3

Description (based on five complete worms and one detached scolex from Tyrannus melancholicus (Vieillot)): Body ribbon-like, up to $31 \mathrm{~mm}(\mathrm{n}=5)$ long, maximum width $810-900(853 \pm 35, \mathrm{n}=5)$ at level of pregravid proglottides (Fig. 1B). Formation of primordial genital organs appearing before external segmentation, which becomes distinct at level of late pre-mature proglottides.
Proglottides slightly craspedote, wider than long when mature (Fig. 3C); craspedote when pregravid and gravid, wider than long, only most terminal gravid proglottides as long as wide (Fig. 3E). Scolex rounded, 760-980 $(878 \pm 80, \mathrm{n}=6)$ in diameter, with 4 round, muscular suckers, 325-360 $(346 \pm 10, \mathrm{n}=24)$ in diameter (Fig. 3A). First proglottides appear $0.37-1.01 \mathrm{~mm}(0.8 \pm 0.3, \mathrm{n}=5)$ from posterior margin of suckers. Mature proglottides appear $2.14 \mathrm{~mm}(\mathrm{n}=1)$ posterior to appearance of first proglottides (Fig. 1B). Genital pores irregularly alternating (e.g. 3, 2, 1, 1, 1, 1, 1, 1, 2, 1 ...), opening in anterior third of lateral margin of mature proglottides and equatorial along lateral edge of post-mature and gravid proglottis. Genital atrium with infundibular orifice, narrow, deep 
Table 2. Key measurements of specimens of Anonchotaenia vaslata sp. n. from various hosts from Paraguay.

\begin{tabular}{|c|c|c|c|c|c|c|c|c|c|}
\hline Catalog number & Host species & Locality & $\begin{array}{c}\text { Scolex } \\
\text { diameter }\end{array}$ & $\begin{array}{c}\text { Sucker } \\
\text { diameter }\end{array}$ & Testis number & $\begin{array}{l}\text { CS length } \\
\text { MP }\end{array}$ & $\begin{array}{l}\text { CS width } \\
\text { MP }\end{array}$ & $\begin{array}{l}\text { CS length } \\
\text { PP }\end{array}$ & $\begin{array}{l}\text { CS width } \\
\text { PP }\end{array}$ \\
\hline MHNG-PLAT 37966 & $\begin{array}{l}\text { Tyrannus } \\
\text { melancholicus } \\
\text { (Viellot) } \\
\text { (Tyrannidae) }\end{array}$ & Paraguay & $\begin{array}{l}1075 \\
\mathrm{n}=1\end{array}$ & $\begin{array}{c}405-425 \\
(411 \pm 10) \\
n=4\end{array}$ & - & $\begin{array}{c}135-150 \\
(143 \pm 6) \\
n=5\end{array}$ & - & - & - \\
\hline MHNG-PLAT 39505 & $\begin{array}{l}\text { Myiodynastes } \\
\text { maculatus } \\
\text { (Statius Muller) } \\
\text { (Tyrannidae) }\end{array}$ & Paraguay & $\begin{array}{l}1075 \\
\mathrm{n}=1\end{array}$ & $\begin{array}{c}390-420 \\
(403 \pm 13) \\
n=4\end{array}$ & $\begin{array}{c}7-10 *(8 \pm 1) \\
{[7(43 \%), 8(43 \%),} \\
9(7 \%), 10(7 \%)]\end{array}$ & $\begin{array}{c}135-150 \\
(141 \pm 8) \\
\mathrm{n}=4\end{array}$ & $\begin{array}{c}50 \\
n=4\end{array}$ & $\begin{array}{c}155-175 \\
(163 \pm 9) \\
n=4\end{array}$ & $\begin{array}{c}40-45 \\
(44 \pm 3) \\
n=4\end{array}$ \\
\hline
\end{tabular}

$\mathrm{CS}$ - cirrus sac; MP - mature proglottides; $\mathrm{PP}$ - pregravid proglottides; * $\mathrm{n}=14$ from 1 worm.

extended tubular middle part, flat base. Genital ducts pass ventrally to osmoregulatory canals. Osmoregulatory canals classically disposed; dorsal osmoregulatory canals $14-18(15 \pm 2, n=4)$ in diameter; ventral osmoregulatory canals $35-43(40 \pm 4, n=4)$ in diameter, with transverse anastomoses along posterior margin of each proglottis.

Testes spherical, slightly oval to oval in contracted proglottides, $45-55(49 \pm 4, \mathrm{n}=10)$ by 40-55 (49 \pm 4 , $\mathrm{n}=10$ ), arranged in single transverse dorsal row, occasionally overlapping osmoregulatory canals; 7-10 [7 (33\%), $8(44 \%), 9(9 \%), 10(14 \%)](8 \pm 1 \mathrm{n}=36)$ in number (Fig. 3C). Cirrus sac pyriform, tapering porally, rounded aporally, muscular, thick-walled (Fig. 3B), $133-153(141 \pm 6, \mathrm{n}=10)$ by $33-48(42 \pm 4, \mathrm{n}=10)$ in mature proglottides (Fig. 3C), 118-170 (143 \pm 19 , n $=8)$ by $38-45(41 \pm 2, \mathrm{n}=8)$ in early pregravid proglottides, reaching but not crossing osmoregulatory canals; length extending $16-18 \%(16 \pm 1 \%, \mathrm{n}=10)$ across width of proglottis. Cirrus unarmed, cylindrical, 10-13 (12 \pm 1 , $\mathrm{n}=10$ ) in diameter. Internal vas deferens forming several coils in aporal portion of cirrus sac. External vas deferens large, wide, prominent, forming coiled mass occupying poral field of proglottis.

Ovary oval, medial, $50-73(64 \pm 6, \mathrm{n}=10)$ by $113-130$ $(120 \pm 5, \mathrm{n}=10)$. Vitellarium compact, circular to oval, $38-60(49 \pm 6, \mathrm{n}=10)$ by $45-75(62 \pm 9, \mathrm{n}=10)$, aporal to ovary. Mehlis' gland indistinct. Seminal receptacle tubular to fusiform. Vagina conspicuous, walls well-demarcated, thick, opening posterior to male pore, separated into copulatory and conductive parts, passing posterior and ventral to cirrus sac and external vas deferens, lumen of copulatory portion crenulated (Fig. 3B).

Uterus in post-mature and early pregravid proglottides circular to oval, sac-like, occupying center of median field, dorsal to vitellarium, expanding to occupy posterior median field in pregravid and gravid proglottides. Uterine wall thickening as proglottis matures. Paruterine organ developing from anterior wall of uterus, conical, consisting of uniform fibrilar tissue, appearing 94 proglottides posterior to first mature proglottides (Fig. 1B); initially directed anteriorly or antero-laterally, curving dorsally in pregravid and gravid proglottides (Fig. 3D,E), curving 63 proglottides posterior to appearance (Fig. 1B). Eggs passing into paruterine cavity observed in terminal proglottis of one worm (Fig. 3E). Gravid proglottides with all eggs completely within paruterine organ not observed. Eggs initially spherical. Oncospheres and embryophore transform into vermiform shape in late pregravid proglottides, appearing approximately 69 proglottides posterior to first appearance of paruterine organ, passing into paruterine cavity in vermiform state. Embryonic hooks present in central portion of vermiform oncospheres.

Ty pe host: Tyrannus melancholicus (Viellot), tropical kingbird (Passeriformes: Tyrannidae).

Type locality: Jejui, San Pedro, Paraguay $\left(24^{\circ} 06^{\prime} \mathrm{S}\right.$; $56^{\circ} 27^{\prime} \mathrm{W}$, elevation $96 \mathrm{~m}$ ).

Site of infection: Small intestine.

Type specimens: MHNG-PLAT 37770: Holotype (in black brackets) and 1 paratype on the same slide, 4 paratypes (3 complete worms and 1 detached scolex) on a separate slide.

Additional material examined: 1 complete worm (MHNG-PLAT 37966) from T. melancholicus from Ar-

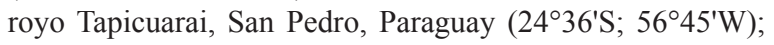
1 complete worm in 4 fragments (MHNG-PLAT 39505) from Myiodynastes maculatus (Statius Muller), streaked flycatcher (Passeriformes: Tyrannidae) from Carapegua, Paraguari, Paraguay $\left(25^{\circ} 44^{\prime} \mathrm{S} ; 57^{\circ} 14^{\prime} \mathrm{W}\right)$.

Etymology: Vas (Latin) - vessel or duct + lata (Latin) broad or wide; referring to the wide external vas deferens observed in this species.

Remarks. The new species presents a combination of characters unique from the other 28 species of Anonchotaenia (Table 1): wide, prominent external vas deferens rather than thin, coiled external vas deferens embedded within dense tissue, a paruterine organ that is conical but curves dorsally (even in relaxed proglottides) rather than a cylindrical, conical and straight, or otherwise shaped paruterine organ, and a long, narrow genital atrium with a flat base rather than short and wide with a rounded base.

Anonchotaenia (Anonchotaenia) vaslata sp. n. possesses genital ducts that pass ventrally to the osmoregulatory canals rather than between the canals as in the four species of Anonchotaenia (Paranonchotaenia): A. dendrocitta, A. malaconoti, A. prionopos and A. prolixa. Anonchotaenia vaslata belongs to a group of 15 Anonchotaenia species that have fewer than 11 but more than 6 testes per proglottis (Table 1). Anonchotaenia vaslata usually possesses 7-8 testes per proglottis unlike Anonchotaeia cas- 


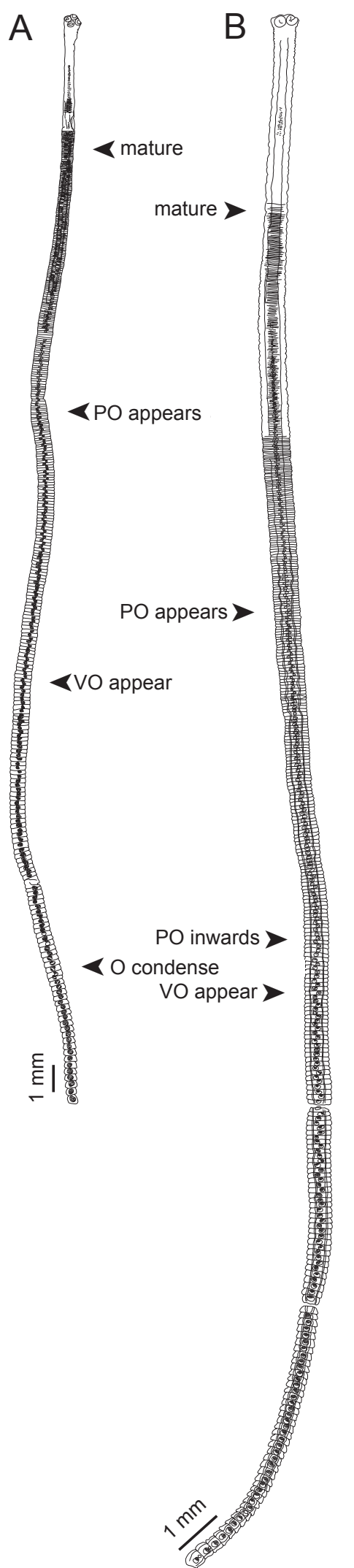

Fig. 4. Drawings of whole worms. A - Anonchotaenia brasiliensis from Tachyphonus coronatus; $\mathbf{B}$ - Anonchotaenia macrocephala from Tachycineta leucorrhoa. Abbreviations: $\mathrm{O}$ - oncospheres; PO - paruterine organ; $\mathrm{VO}$ - vermiform oncospheres. tellani Fuhrmann et Baer, 1943 (usually 9-10), Anonchotaenia clelandi (Johnston, 1912) (usually 5), or A. globata (usually 4-5). Testes of the new species occur in a single transverse row rather than clustered in two groups as in Anonchotaenia yadavi Sharma et Mathur, 1987 and Anonchotaenia quiscali Rausch et Morgan, 1947.

Anonchotaenia vaslata possesses a longer cirrus sac $(133-153 \mu \mathrm{m})$ than Anonchotaenia arhyncha Fuhrmann, $1918(80-90 \mu \mathrm{m})$; this further differentiates the new species from A. brasiliensis $(62.5-89 \mu \mathrm{m})$, Anonchotaenia longiovata Fuhrmann, 1901 (67-96 $\mu \mathrm{m})$, A. ranae (50-62.5 $\mu \mathrm{m})$, A. yadavi $(19-110 \mu \mathrm{m})$, A. castellani (103-115 $\mu \mathrm{m})$, A. zanthopygiae $(60-100 \mu \mathrm{m})$, and A. clelandi $(52-58 \mu \mathrm{m})$. The cirrus sac of $A$. vaslata reaches the osmoregulatory canals unlike Anonchotaenia antirina Singal, 1964, A. brasiliensis, A. indica Singh, 1964, A. longiovata, A. ranae, and A. zanthopygiae and is further differentiated from $A$. globata in this respect.

The new species possesses a larger scolex $(760-980 \mu \mathrm{m})$ than A. quiscali $(580 \mu \mathrm{m})$, A. mexicana (522-612 $\mu \mathrm{m})$, A. zanthopygiae (550-650 $\mu \mathrm{m})$ and A. globata $(500-700 \mu \mathrm{m})$, further differentiating the new species from these taxa. The new species differs from Anonchotaenia lambi (Voge et Davis, 1953) in the possession of a smaller scolex (760-980 $\mu \mathrm{m}$ rather than $1120 \mu \mathrm{m})$ and a shorter cirrus sac $(102-118 \mu \mathrm{m}$ rather than 133-153 $\mu \mathrm{m})$. Anonchotaenia vaslata possesses larger suckers $(325-360 \mu \mathrm{m})$ than $A$. mexicana $(121-198 \mu \mathrm{m})$ as well as a wider cirrus sac $(33-48 \mu \mathrm{m}$ rather than 19-27 $\mu \mathrm{m}$ in A. mexicana).

Material included here from T. melancholicus (MHNGPLAT-37966) and M. maculatus (MHNG-PLAT 39505) is morphologically consistent with the type specimens (Table 2); M. maculatus represents an additional host record for $A$. vaslata.

Additional specimens examined in this study were found not to be conspecific with A. vaslata (Table S2). Specimens from Paraguay (MHNG-PLAT 37807 and MHNG-PLAT 39512) resemble $A$. vaslata in the form of the external vas deferens, paruterine organ, and genital atrium but differ in the possession of a smaller scolex (410-530 $\mu \mathrm{m}$ rather than 760-1075 $\mu \mathrm{m}$ ), smaller suckers (170-195 $\mu \mathrm{m}$ rather than 325-425 $\mu \mathrm{m}$ ) and a shorter cirrus sac $(92.5-110 \mu \mathrm{m}$ rather than 133-153 $\mu \mathrm{m})$. Specimens from Bolivia (MHNG-PLAT 83085) resemble $A$. vaslata in the form of the external vas deferens, paruterine organ and genital atrium, but differ in the possession of a higher number of testes per proglottis (8-12, usually 10 rather than $7-10$, usually 7 or 8 ). For these reasons, this material has not been included in the type series of the new species.

Anonchotaenia (Anonchotaenia) brasiliensis Fuhrmann, 1908

Figs. 4A, 5, 6A-C, 7

Redescription (based on eight complete worms and one scolex prepared for SEM from T. coronatus from Bra- 
A

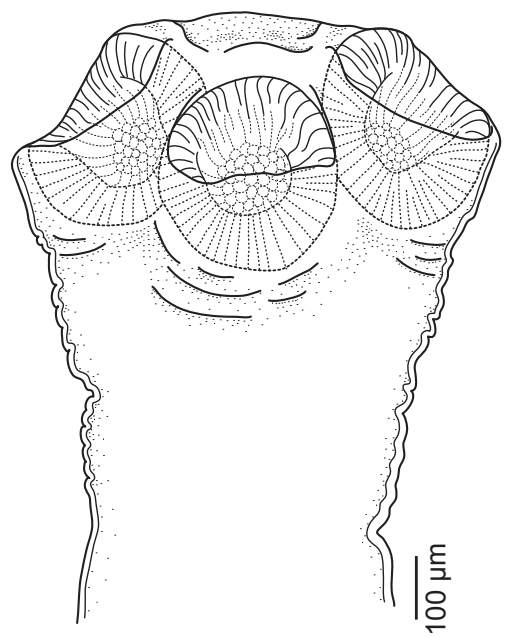

C

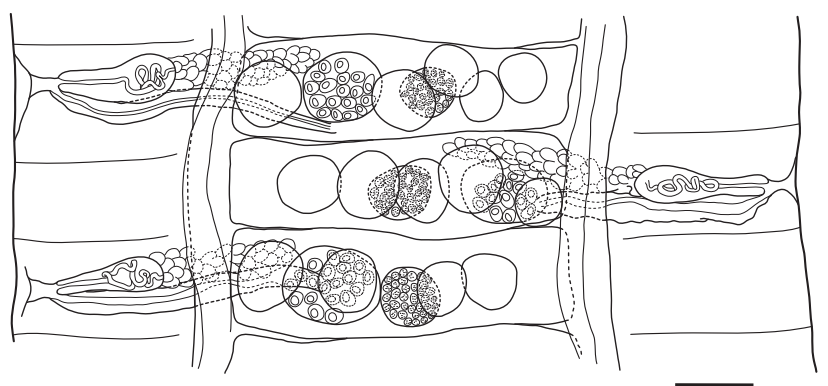

$E$

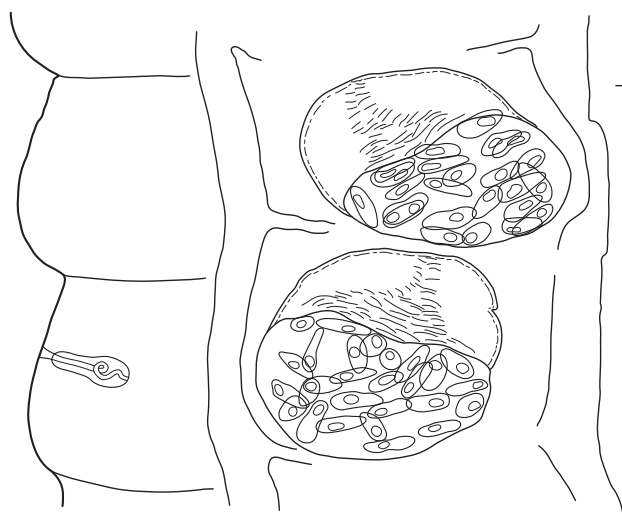

B
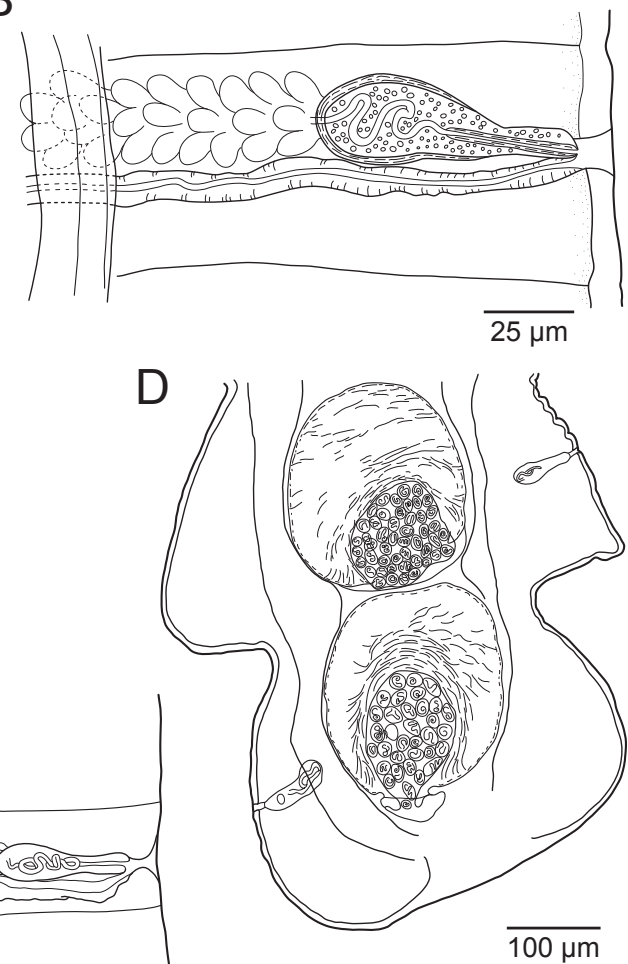

$\mathrm{F}$

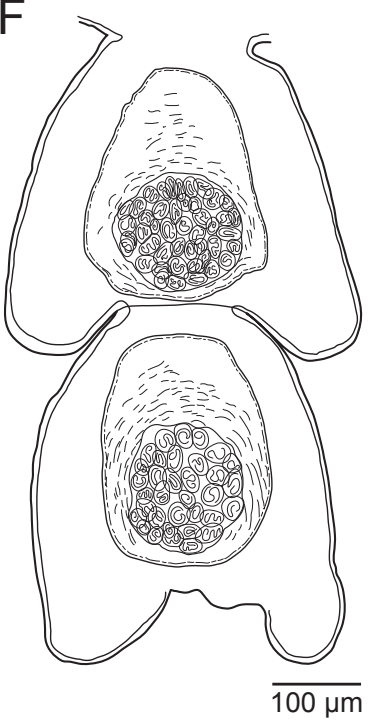

Fig. 5. Anonchotaenia brasiliensis: Brazilian material from Tachyphonus coronatus (A-E) and Paraguayan material from Thraupis sayaca $(\mathrm{F})$. A - scolex; B - mature proglottids; C - terminal genital ducts; D - gravid proglottides with eggs passing into the paruterine organ; $\mathbf{E}$ - pre-gravid proglottides; $\mathbf{F}$ - gravid proglottides with eggs in the paruterine organ.

zil): Body ribbon-like, 31-47 (38 $\pm 6 \mathrm{~mm}, \mathrm{n}=6)$ in length, maximum width 593-696 (636 $\pm 33, \mathrm{n}=6)$, at level of pregravid proglottides (Fig. 4A). External segmentation lacking at level of developed mature proglottides (Fig. 5C). Mature, post-mature and early pregravid proglottides slightly craspedote, wider than long (Fig. 5C); late pregravid proglottides slightly craspedote, as wide as long (Fig. 5E). Scolex rounded, 497-696 (628 $\pm 70, \mathrm{n}=7)$ in diameter, with 4 round, muscular suckers, 222-271
$(247 \pm 13, \mathrm{n}=28)$ in diameter (Figs. 5A, 6A). Sucker proximal and distal surfaces covered by acicular filitriches (Fig. 6B,C). First proglottides appear 1.0-1.4 mm $(1.2 \pm 1, \mathrm{n}=7)$ from posterior margin of suckers. Mature proglottides appearing approximately $3.56 \mathrm{~mm}(\mathrm{n}=1)$ from posterior margin of suckers (Fig. 4A). Genital pores irregularly alternating in short series (e.g. 2, 1, 1, 2, 1, 3, $1,2,2,1,1,1,1,1,1 \ldots)$; opening equatorial along lateral edge of proglottis. Genital atrium with infundibular 


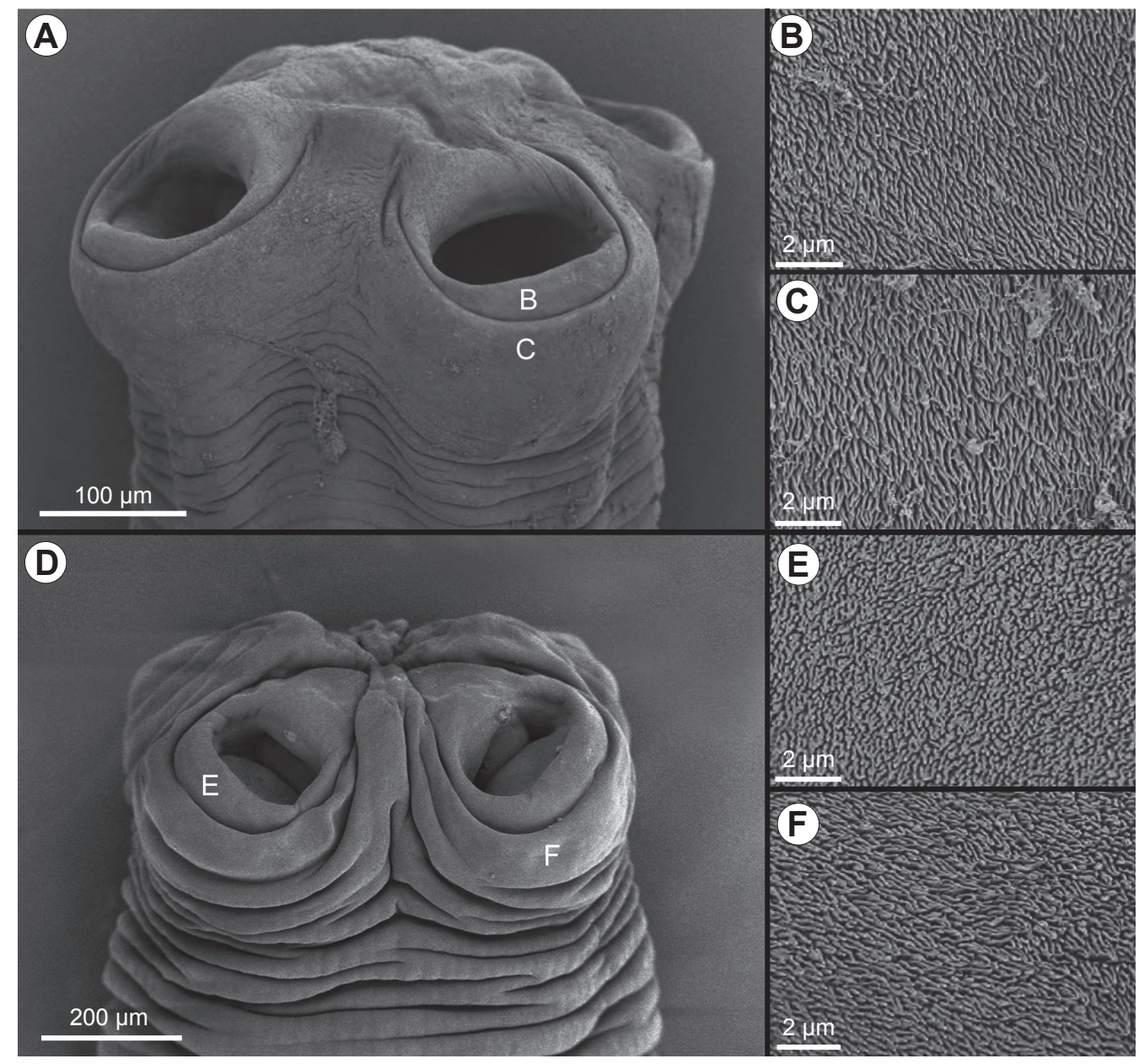

Fig. 6. Scanning electron micrographs: Anonchotaenia brasiliensis from Tachyphonus coronatus (A-C) and Anonchotaenia macrocephala (D-F). A - scolex; B - proximal surface of a sucker; C - distal surface of a sucker; D - scolex; $\mathbf{E}$ - proximal surface of a sucker; $\mathbf{F}$ - distal surface of a sucker.

orifice, tubular. Genital ducts pass ventral to osmoregulatory canals. Osmoregulatory canals classically disposed; dorsal osmoregulatory canals $8-18(11 \pm 2, \mathrm{n}=23)$ in diameter; ventral osmoregulatory canals $17-25(21 \pm 2$, $\mathrm{n}=18$ ) in diameter; transverse anastomoses along posterior margin of each proglottis.

Testes spherical, circular to oval in contracted proglottides, 4-8 [4 (2\%), 5 (30\%), 6 (45\%), 7 (19\%), 8 (4\%)] $(6 \pm 2, n=112)$ in number; arranged irregularly across proglottis in single plane, sometimes overlapping; $29-51$ $(43 \pm 6, \mathrm{n}=38)$ by $24-46(37 \pm 6, \mathrm{n}=38)$, occasionally overlapping margins of ventral osmoregulatory canal (Fig. 5C). Cirrus sac pyriform, tapering slightly porally and aporally, muscular, thick-walled (Fig. 5B), 62.5-89 $(73 \pm 7, \mathrm{n}=25)$ by $20-30(25 \pm 2, \mathrm{n}=25)$ in mature proglottides (Fig. 5C), 65-89 $(76 \pm 5, \mathrm{n}=25)$ by $20-35$ $(28 \pm 4, n=25)$ in early pregravid proglottides, not reaching osmoregulatory canals, length extending $11-20 \%$ $(14 \pm 2 \%, n=40)$ across width of proglottis. Cirrus unarmed, cylindrical. Internal vas deferens forming several coils in aporal portion of cirrus sac. External vas deferens forming coiled mass, occupying anterior poral portion of median field of proglottis.

Ovary round to oval, poral, 36-62 $(50 \pm 7, \mathrm{n}=28)$ by 45-94 $(67 \pm 10, \mathrm{n}=28)$. Vitellarium compact, circular, $31-48(38 \pm 4, n=28)$ by $34-53(45 \pm 5, n=28)$, medial. Mehlis' gland not distinct. Seminal receptacle fusiform. Vagina tubular, opening posterior to male pore, not clearly separated into copulatory and conductive parts, passing posteriorly to cirrus sac, sometimes overlapping slightly, intertwining with external vas deferens (Fig. 5B). Uterus circular to oval, sac-like, dorsal to vitellarium, expanding to occupy entire medial field in pregravid (Fig. 5E) and gravid proglottides (Fig. 5D,F). Paruterine organ conical, consisting of uniform fibrilar tissue, developing as thickening of anterior uterine wall, appearing approximately 145 proglottides posterior to first mature proglottides (Fig. 4A), initially directed anteriorly or anterolaterally; in late pregravid proglottides broadening, joining uterus to form spherical shape (Fig. 5E). Eggs initially spherical. In pregravid proglottides oncospheres and embryophore transform into vermiform shape approximately 98 
Table 3. Key measurements of type material and specimens of Anonchotaenia brasiliensis from various localities and host species and $A$. cf. brasiliensis from Brazil.

\begin{tabular}{|c|c|c|c|c|c|c|c|c|c|c|}
\hline Catalog number & Host species & Locality & $\begin{array}{l}\text { Scolex } \\
\text { diameter }\end{array}$ & $\begin{array}{l}\text { Sucker } \\
\text { diameter }\end{array}$ & $\begin{array}{l}\text { Testes } \\
\text { number }\end{array}$ & $\begin{array}{c}\text { CS } \\
\text { extent }\end{array}$ & $\begin{array}{l}\text { CS length } \\
\text { MP }\end{array}$ & $\begin{array}{l}\text { CS width } \\
\text { MP }\end{array}$ & $\begin{array}{l}\text { CS length } \\
\text { PP }\end{array}$ & $\begin{array}{l}\text { CS width } \\
\text { PP }\end{array}$ \\
\hline $\begin{array}{l}\text { MHNG-PLAT } 40213 \\
\text { (type material) }\end{array}$ & $\begin{array}{l}\text { Cacicus } \\
\text { haemorrhous } \\
\text { (Linnaeus) } \\
\text { (Icteridae) }\end{array}$ & Brazil & - & - & - & $\begin{array}{c}8-11 \% \\
(10 \pm 1 \%) \\
n=6\end{array}$ & $\begin{array}{c}53-75 \\
(65 \pm 8) \\
n=6\end{array}$ & $\begin{array}{c}33-40 \\
(36 \pm 3) \\
n=6\end{array}$ & $\begin{array}{c}68-78 \\
(72 \pm 4) \\
n=6\end{array}$ & $\begin{array}{c}38-43 \\
(40 \pm 2) \\
n=6\end{array}$ \\
\hline $\begin{array}{l}\text { MZUSP 7191, } \\
\text { MZUSP 7192, } \\
\text { MZUSP } 7193\end{array}$ & $\begin{array}{l}\text { Thraupis } \\
\text { cyanoptera } \\
\text { (Viellot) } \\
\text { (Thraupidae) }\end{array}$ & Brazil & $\begin{array}{c}536-559 \\
(547 \pm 16) \\
\mathrm{n}=2\end{array}$ & $\begin{array}{c}202-241 \\
(228 \pm 14) \\
\mathrm{n}=8\end{array}$ & ) & - & $\begin{array}{c}74-86 \\
(80 \pm 4) \\
n=10\end{array}$ & $\begin{array}{c}23-31 \\
(27 \pm 3) \\
n=10\end{array}$ & $\begin{array}{c}78-106 \\
(92 \pm 9) \\
n=10\end{array}$ & $\begin{array}{c}21-35 \\
(27 \pm 4) \\
n=10\end{array}$ \\
\hline $\begin{array}{l}\text { MHNG-PLAT } 39504, \\
\text { MHNG-PLAT } 39531\end{array}$ & $\begin{array}{l}\text { Tharupis } \\
\text { sayaca } \\
\text { (Linnaeus) } \\
\text { (Thraupidae) }\end{array}$ & Paraguay & $\begin{array}{c}425-600 \\
(512 \pm 61) \\
n=8\end{array}$ & $\begin{array}{c}160-240 \\
(200 \pm 23) \\
n=32\end{array}$ & $\begin{array}{c}5-8 *(7 \pm 0.8) \\
{[5(2 \%), 6} \\
(32 \%), 7(42 \%) \\
8(24 \%)]\end{array}$ & $\begin{array}{c}11-18 \% \\
(15 \pm 2 \%) \\
\mathrm{n}=10\end{array}$ & $\begin{array}{c}69-95 \\
(79 \pm 8) \\
n=10\end{array}$ & $\begin{array}{c}25-35 \\
(28 \pm 3) \\
n=10\end{array}$ & $\begin{array}{c}65-88 \\
(73 \pm 7) \\
n=10\end{array}$ & $\begin{array}{c}20-33 \\
(26 \pm 4) \\
n=10\end{array}$ \\
\hline $\begin{array}{l}\text { MHNG-PLAT } 39494, \\
\text { MHNG-PLAT } 82656\end{array}$ & $\begin{array}{l}\text { Volatinia } \\
\text { jacarina } \\
\text { (Linnaeus) } \\
\text { (Thraupidae) }\end{array}$ & Paraguay & $\begin{array}{c}335-440 \\
(392 \pm 38) \\
n=6\end{array}$ & $\begin{array}{c}154-183 \\
(167 \pm 7) \\
n=24\end{array}$ & - & - & - & - & $\begin{array}{c}57-89 \\
(70 \pm 12) \\
\mathrm{n}=7\end{array}$ & $\begin{array}{c}17-22 \\
(20 \pm 2) \\
n=7\end{array}$ \\
\hline $\begin{array}{l}\text { MZUSP } 7284 \\
\text { (Anonchotaenia } \mathrm{cf} . \\
\text { brasiliensis) }\end{array}$ & $\begin{array}{l}\text { Ammodramus } \\
\text { humeralis } \\
\text { (Bosc) } \\
\text { (Emberizidae) }\end{array}$ & Brazil & $\begin{array}{c}424-562 \\
(465 \pm 65) \\
n=4\end{array}$ & $\begin{array}{c}179-222 \\
(196 \pm 13) \\
\mathrm{n}=16\end{array}$ & $\begin{array}{c}4-8 * *(6 \pm 1) \\
{[4(1 \%), 5} \\
(26 \%), 6(46 \%), \\
7(21 \%), 8(6 \%)\end{array}$ & $\begin{array}{c}9-13 \% \\
(11 \pm 1 \%) \\
n=10\end{array}$ & $\begin{array}{c}64-81 \\
(72 \pm 5) \\
n=10\end{array}$ & $\begin{array}{c}25-33 \\
(29 \pm 2.5) \\
n=10\end{array}$ & $\begin{array}{c}64-89 \\
(76 \pm 7) \\
n=10\end{array}$ & $\begin{array}{c}21-30 \\
(26 \pm 3) \\
n=10\end{array}$ \\
\hline
\end{tabular}

$\mathrm{CS}$ - cirrus sac; MP - mature proglottides; PP - pregravid proglottides; * $\mathrm{n}=50$ from 3 worms; ** $\mathrm{n}=200$ from 4 worms.

A

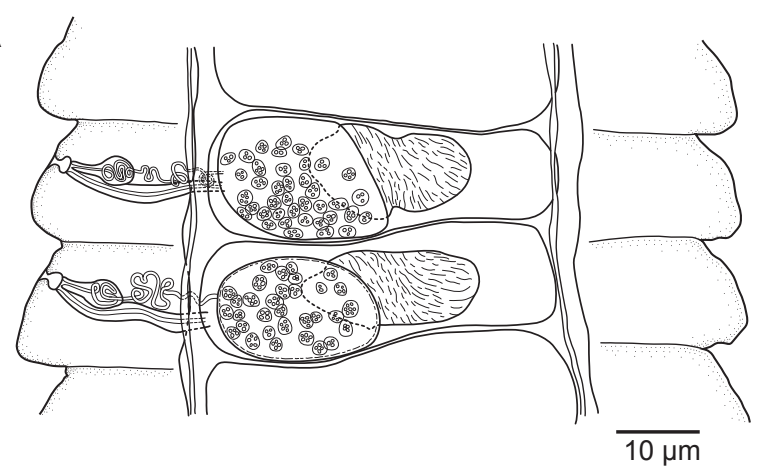

B

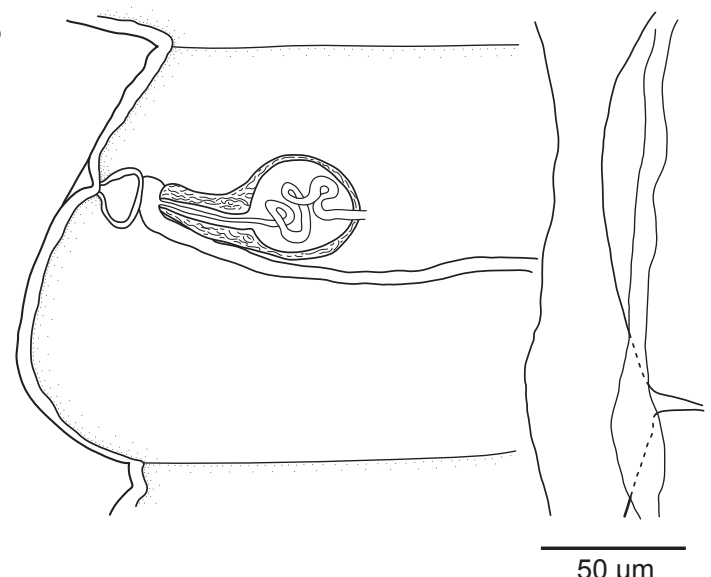

Fig. 7. Anonchotaenia brasiliensis, syntype: MHNG-PLAT 40213 from Cacicus haemorrhous. A - pregravid proglottides; B - terminal genital ducts.

proglottides posterior to appearance of paruterine organ (Fig. 4A); in late pregravid proglottides embryophore condensing into round shape with coiled vermiform oncospheres approximately 64 proglottides posterior to ap- pearance of paruterine organ (Fig. 4A). Oncospheres pass into paruterine organ in coiled state (Fig. 5D). Embryonic hooks not observed.

Material examined: From Tachyphonus coronatus (Vieillot), ruby-crowned tanager (PBI BRE-094) (Passeriformes: Thraupidae): 8 complete worms and 1 scolex prepared for SEM (MZUSP 7213, 7214) from Boracéia Biological Station, Salesópolis, São Paulo, Brazil (233' S; $45^{\circ} 52^{\prime} \mathrm{W}$, elevation $946 \mathrm{~m}$ ).

Additional material examined: From Cacicus haemorrhous (Linnaeus), red-rumped cacique (Passeriformes: Icteridae): 2 syntypes and 3 slides of longitudinal sections (MHNG-PLAT 40213) from 'San Paulo', Brazil (GPS data not specified); from Thraupis cyanoptera (Viellot), azure-shouldered tanager (PBI BRE-070) (Passeriformes: Thraupidae): 3 contracted worms (MZUSP 7191-7193) and 1 detached scolex prepared for SEM from Boracéia Biological Station, Salesópolis, São Paulo, Brazil $\left(23^{\circ} 38^{\prime} \mathrm{S}\right.$; 4552'W; elevation $\left.946 \mathrm{~m}\right)$; from Thraupis sayaca (Linnaeus), sayaca tanager (Passeriformes: Thraupidae): 2 worms with contracted strobila (MHNG-PLAT 39504) from Carapegua, Paraguari, Paraguay $\left(25^{\circ} 44^{\prime} \mathrm{S} ; 57^{\circ} 15^{\prime} \mathrm{W}\right.$; elevation $92 \mathrm{~m}$ ); 1 complete worm, 5 worms with incomplete strobila, 14 fragments of strobila, 1 detached scolex (MHNG-PLAT 39531) from San Lorenzo, Central, Paraguay $\left(25^{\circ} 18^{\prime} \mathrm{S}\right.$; $57^{\circ} 30^{\prime} \mathrm{W}$, elevation $\left.146 \mathrm{~m}\right)$; from Volatinia jacarina (Linnaeus), blue-black grassquit (Passeriformes: Thraupidae): 3 worms with incomplete strobila and 2 fragments of strobila (MHNG-PLAT 39494) from Carapa, Canendiyu, Paraguay $\left(24^{\circ} 08^{\prime} 24^{\prime \prime} \mathrm{S} ; 55^{\circ} 40^{\prime} 12^{\prime \prime} \mathrm{W}\right.$, elevation $\left.143 \mathrm{~m}\right) ; 3$ complete worms and 3 fragments of strobila (MHNG-PLAT 82656) from Bahia Asunción, Distrito de la Capital, Paraguay $\left(27^{\circ} 16^{\prime} 22^{\prime \prime} \mathrm{S} ; 57^{\circ} 37^{\prime} 37^{\prime \prime} \mathrm{W}\right.$, elevation $\left.c a 61 \mathrm{~m}\right)$.

Prevalence and intensity of infection: From 


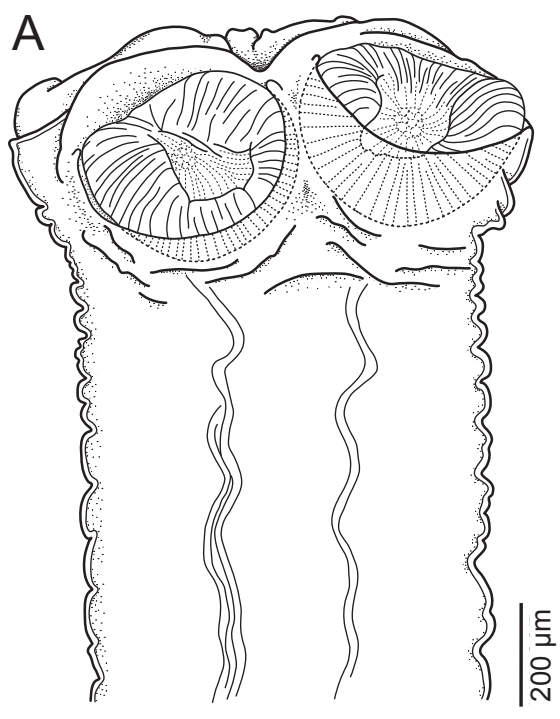

$\mathrm{D}$
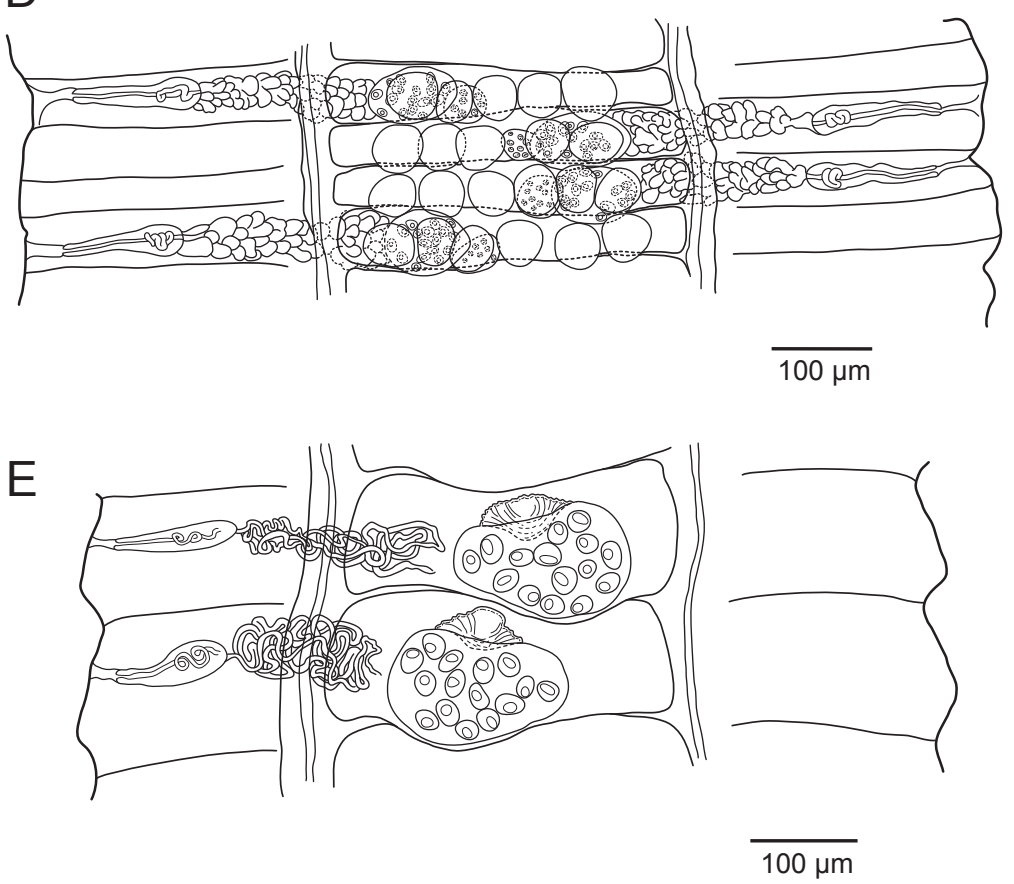

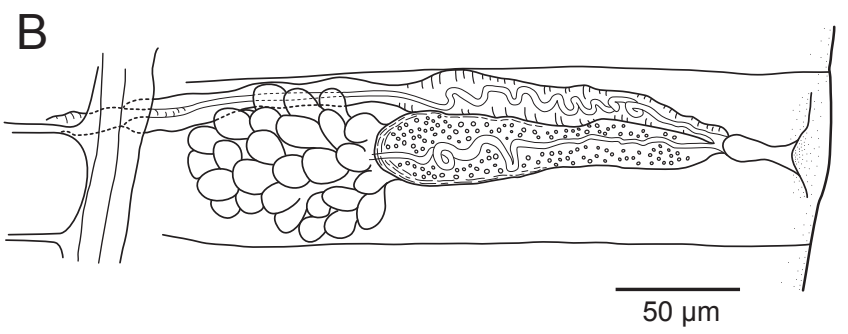

C
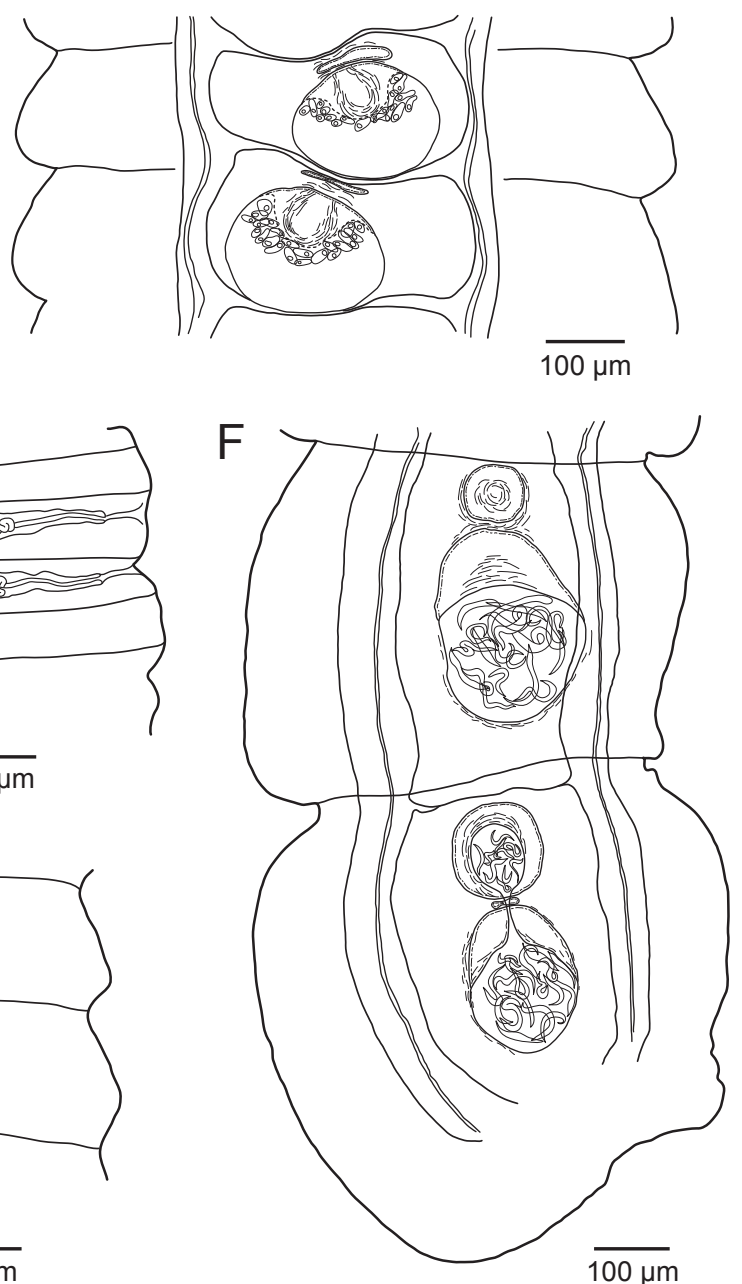

Fig. 8. Anonchotaenia macrocephala from Tachycineta leucorrhoa. A - scolex; B - terminal genital ducts; $\mathbf{C}$ - late pre-gravid proglottides; D - mature proglottides; $\mathbf{E}$ - early pre-gravid proglottides; $\mathbf{F}$ - gravid proglottides with eggs passing into the paruterine organ.

T. coronatus, 14\% (1 host infected of 7 examined), 25 worms; from T. cyanoptera, $25 \%$ (1 host infected of 4 examined), 7 worms.

Remarks. The original description of $A$. brasiliensis by Fuhrmann (1908) was very brief and included measurements and information about few, yet essential, characters without illustrations. The present redescription expands the range and provides information on additional morphological features with illustrations and scanning electron micrographs (see Figs. 5 and $6 \mathrm{~A}-\mathrm{C}$ for the morphology of newly collected specimens and Fig. 7A,B for syntype morphology). Anonchotaenia brasiliensis is now characterised by its possession of five to eight, but usually six, testes per proglottis, a scolex 497-696 $\mu \mathrm{m}$ in diameter, suckers $223-271 \mu \mathrm{m}$ in diameter, a cirrus sac $62-89 \mu \mathrm{m}$ in length in mature proglottides, and a conical paruterine organ.

Prior to this study, A. brasiliensis had only been reported from $C$. haemorrhous and Hemignathus virens (Gmelin) (see Fuhrmann 1908, van Riper 1991). Material included here from $T$. coronatus, T. cyanoptera, T. sayaca and $V$. jacarina is morphologically consistent with 
A

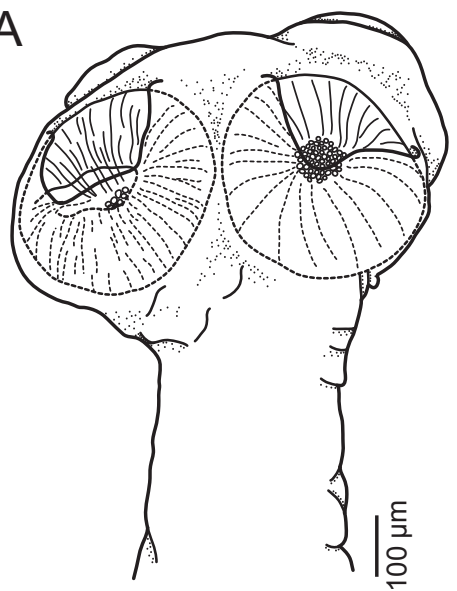

B

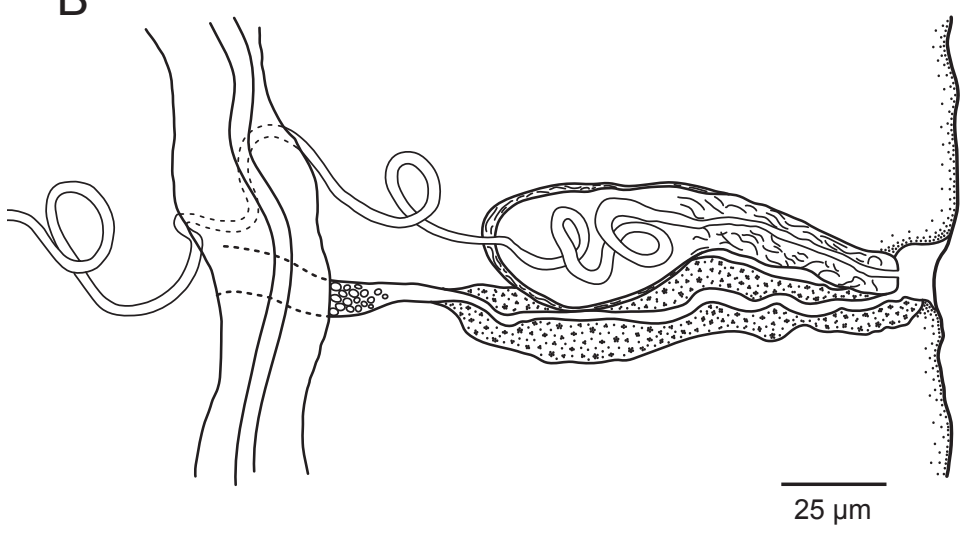

Fig. 9. Anonchotaenia macrocephala from Progne 'purpurea', syntype: MHNG-PLAZ 40225. A - scolex; B - terminal genital ducts.

specimens from the type host, C. haemorrhous (Table $3)$. These species represent new host genus records and Thraupidae is a new host family record for A. brasiliensis. Specimens from the MHNG extend the geographic range of the species beyond Brazil to include areas in Paraguay.

Specimens from Ammodramus humeralis (Bosc), grassland sparrow (Passeriformes: Emberizidae) (MZUSP 7284) from Boracéia Biological Station, Salesópolis, São Paulo, Brazil (233' S; 4552'W, elevation $946 \mathrm{~m})$ are morphologically indistinguishable from $A$. brasiliensis, but the results of molecular analyses suggest they represent a species distinct from $A$. brasiliensis. As a result, these specimens were not included in the redescription based on the results of the molecular phylogeny and are referred to as $A$. cf. brasiliensis PBI-228.

\section{Anonchotaenia (Anonchotaenia) macrocephala} Fuhrmann, 1908

Figs. 4B, 6D-F, 8-10

Redescription (one complete worm, two fragments of strobila and one scolex prepared for SEM from T. leucorrhoa from Brazil): Body ribbon-like, up to $59 \mathrm{~mm}$ long $(\mathrm{n}=1)$, maximum width 878-1011 (963 $\pm 59, \mathrm{n}=3)$, at level of pregravid proglottides (Fig. 4B). Proglottides acraspedote, wider than long in mature, post-mature and young pregravid (Fig. 8D,E); slightly craspedote, as wide as long or longer than wide in late pregravid and gravid proglottides (Fig. 8C,F). Scolex rounded, massive, $994(\mathrm{n}=1)$ in diameter with 4 round, muscular suckers, 412-428 (419 $\pm 7, \mathrm{n}=4)$ in diameter (Figs. 6D, 8A). Sucker proximal and distal surfaces covered by acicular filitriches (Fig. 6E,F). First proglottides appear $1.9 \mathrm{~mm}$ $(n=1)$ from posterior margin of suckers. Mature proglottides appear approximately $3 \mathrm{~mm}(\mathrm{n}=1)$ from posterior margin of suckers (Fig. 2B). Genital pores irregularly alternating in short series (e.g. 3, 2, 1, 1, 1, 1, 1, 1, 2, 1, $2,1,2,1,1 \ldots)$, opening equatorial along lateral edge of proglottis. Genital atrium with infundibular orifice, pyri- form. Genital ducts pass ventrally to osmoregulatory canals. Osmoregulatory canals classically disposed; dorsal osmoregulatory canals 6-12 $(9 \pm 2, \mathrm{n}=12)$ in diameter; ventral osmoregulatory canals $22-57(31 \pm 10, \mathrm{n}=12)$ in diameter; transverse anastomoses along posterior margin of each proglottis.

Testes spherical, slightly oval to oval in contracted proglottides; 4-8 [4 (4\%), 5 (17\%), 6 (36\%), 7 (32\%), $8(11 \%)](6 \pm 1, \mathrm{n}=95)$ in number, arranged in single dorsal transverse row, 29-55 (43 $\pm 7, \mathrm{n}=37)$ by 31-57 ( $44 \pm 7, n=37)$, not overlapping marginal osmoregulatory canals (Fig. 8D), persist in pregravid proglottides. Cirrus sac pyriform, tapering porally, rounded aporally, muscular, thick-walled (Fig. 8B), 104-178 (137 $\pm 19, \mathrm{n}=24)$ by $25-34(30 \pm 3, \mathrm{n}=24)$ in mature proglottides, $93-125$ $(113 \pm 9, \mathrm{n}=24)$ by $23-31(28 \pm 2, \mathrm{n}=24)$ in early pregravid proglottides, not reaching osmoregulatory canals; length extending $10-17 \%(13 \pm 1 \%, \mathrm{n}=28)$ across width of proglottides (Fig. 8D,E). Cirrus unarmed, cylindrical. Internal vas deferens forming several coils in aporal portion of cirrus sac. External vas deferens appearing as bulbous mass in mature proglottides, developing into coiled, tubular mass in pregravid proglottides, occupying poral portion of median field.

Ovary round to oval, poral, 44-65 $(54 \pm 7, \mathrm{n}=17)$ by $57-105(89 \pm 13, \mathrm{n}=17)$. Vitellarium compact, circular, medial, $30-50(39 \pm 6, \mathrm{n}=17)$ by $35-55(43 \pm 6$, $\mathrm{n}=17$ ). Mehlis' gland not distinct. Seminal receptacle fusiform. Vagina narrow, opening posterior to male pore, not clearly separated into copulatory and conductive parts, passing posteriorly to cirrus sac (Fig. 8B). Uterus circular to slightly oval, sac-like, occupying median field in post-mature and early pregravid proglottides. Paruterine organ consisting of uniform fibrilar tissue, developing as thickening of anterior uterine wall, initially conical, directed anteriorly (Fig. 8E), appearing approximately 150 proglottides posterior to first mature proglottides 


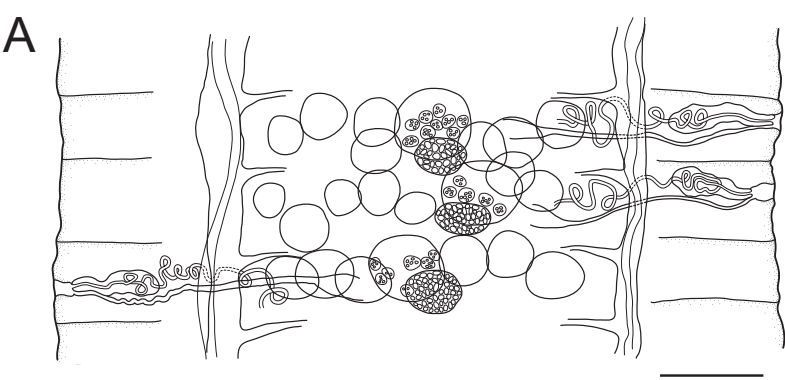

B

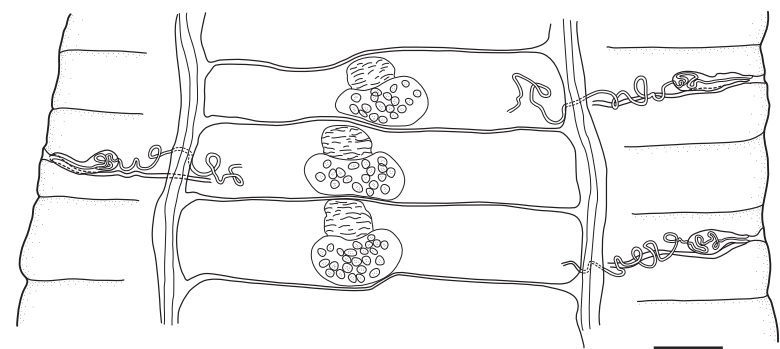

$\overline{100 \mu \mathrm{m}}$
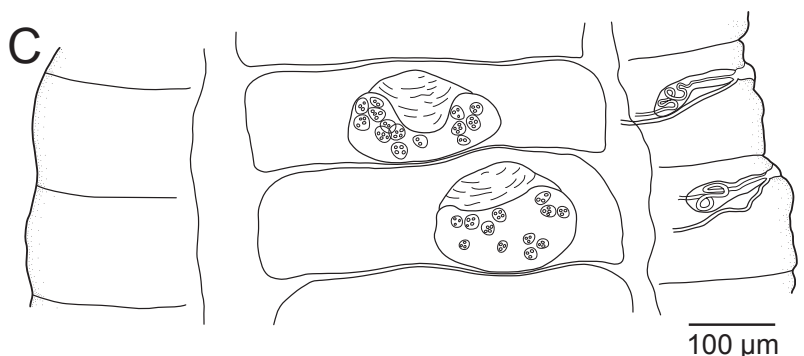

Fig. 10. Anonchotaenia macrocephala from Progne 'purpurea', syntype: MHNG-PLAZ 40225. A - mature proglottides; $\mathbf{B}$ - early pregravid proglottides; $\mathbf{C}$ - late pregravid proglottides.

(Fig. 4B). In pregravid proglottides pressing posteriorly into anterior uterine wall to form conical pocket inside uterine margins, but not invading uterus (Fig. 8C), approximately 105 proglottides posterior to appearance of paruterine organ (Fig. 4B). Eggs passing into paruterine cavity observed in terminal proglottis (Fig. 8F). Gravid proglottides with all eggs completely within paruterine cavity not observed. Eggs initially spherical. In pregravid proglottides oncospheres and embryophore transform into vermiform shape approximately 112 proglottides posterior to appearance of paruterine organ (Fig. 4B), pass into paruterine cavity in vermiform state (Fig. 8F). Embryonic hooks not observed.

Material examined: From Tachycineta leucorrhoa (Vieillot), white-rumped swallow (PBI BRE-211) (Passeriformes: Hirundinidae): 1 complete worm, 2 fragments of strobila, and 1 scolex prepared for SEM (MZUSP 7313, MZUSP 7314) from Boracéia Biological Station, Salesópo-

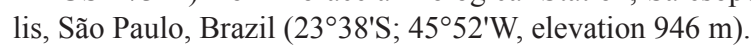

Additional material examined:

From Progne purpurea [sic] (most likely Progne subis (Linnaeus), purple martin) (Passeriformes: Hirundinidae): 2 syn- types (MHNG-PLAT 40225) from Brazil (exact locality is unknown); from Progne tapera (Linnaeus), brown-chested martin (Passeriformes: Hirundinidae): 1 syntype (MHNGPLAT-40266) from Brazil (exact locality is unknown); from Progne chalybea (Gmelin), grey-breasted martin (Passeriformes: Hirundinidae): 3 syntypes (MHNG-PLAT 40227) from Brazil (exact locality is unknown); 4 complete worms and 4 fragments of strobila (MHNG-PLAT 37772) from Jejui, San Pedro, Paraguay $\left(24^{\circ} 06^{\prime} \mathrm{S} ; 5^{\circ} 27^{\prime} \mathrm{W}\right.$, elevation 96 $\mathrm{m}) ; 4$ complete worms and 2 fragments of strobila (MHNGPLAT 39528) from Caicisa, Itapua, Paraguay (26¹9'12"S; $55^{\circ} 13^{\prime} 11^{\prime \prime} \mathrm{W}$, elevation $324 \mathrm{~m}$ ); 2 worms with contracted strobila and 1 fragment of strobila (MHNG-PLAT 39529) from

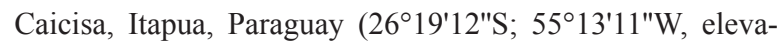
tion $324 \mathrm{~m}$ ); 1 complete worm (MHNG-PLAT 39519) from Santa Maria, Itapua, Paraguay (26 53'59"S; 5549'12"W, elevation $206 \mathrm{~m}$ ); from Hirundo sp. (Passeriformes: Hirundinidae): 1 syntype (MHNG-PLAT 40229) from Brazil (exact locality is unknown); from Hirondella sp. [sic] (Passeriformes: Hirundinidae): 2 syntypes (MHNG-PLAT-40577) from Brazil (exact locality is unknown); from Tachycineta meyeni (Cabanis), Chilean swallow (PBI-CHI-043): 5 worms (MHNG-PLAT 83087) from Huinay Station, Comau Fjord, Los Lagos Region, Chile (42²2'47"S; 72²4'54"W, elevation $22 \mathrm{~m}$ ); from Stelgidopteryx ruficollis (Vieillot), southern rough-winged swallow: 3 complete worms and 7 fragments of strobila (MHNG-PLAT 39521), 3 complete worms and 4 fragments of strobila (MHNG-PLAT 39522), and 2 worms with incomplete strobila and 2 fragments of strobila (MHNG-PLAT-39523), all from San Benito (Pastoreo), Itapua, Paraguay (26 48'35"S; 55 $43^{\circ} 11^{\prime \prime} \mathrm{W}$, elevation $207 \mathrm{~m}$ ).

Prevalence and intensity of infection: 1 T.leucorrhoa infected of 1 examined, 2 worms; from T. meyeni, $16.7 \%$ ( 1 host infected of 6 examined), 2 worms.

Remarks. The original description of A. macrocepha$l a$ is brief and included measurements and descriptions of few, yet essential, characters. Fuhrmann (1908) described A. macrocephala as possessing 10-13 testes per proglottis, but examination of the type material showed the syntypes to actually possess 6-10 testes per proglottis (Table 4, Fig. 9). This redescription shifts the range of testes per proglottis from 10-13 to 6-10 and contributes information about additional morphological features with illustrations and scanning electron micrographs (see Figs. 6D-F, 8 for morphology of newly collected specimens and Figs. 9A,B, 10A-C for syntype morphology). Fuhrmann (1908) does not mention the change of paruterine organ shape we observed in pregravid proglottides, although the description included an illustration of a proglottis with a conical paruterine organ projecting anteriorly from the uterus. This illustration resembles the shape of the paruterine organ we observed in post-mature proglottides of newly collected material and the unique shape of the paruterine organ was observed in pregravid proglottides of the type material (Fig. 10C). Anonchotaenia macrocephala is 
Phillips et al.: Anonchotaenia spp. from South American birds

Table 4. Key measurements of specimens of Anonchotaenia macrocephala from various localities and host species.

\begin{tabular}{|c|c|c|c|c|c|c|c|c|c|c|}
\hline Catalog number & Host species & Locality & $\begin{array}{l}\text { Scolex } \\
\text { diameter }\end{array}$ & $\begin{array}{l}\text { Sucker } \\
\text { diameter }\end{array}$ & $\begin{array}{l}\text { Testes } \\
\text { number }\end{array}$ & CS extent & $\begin{array}{l}\text { CS length } \\
\text { MP }\end{array}$ & $\begin{array}{l}\text { CS width } \\
\text { MP }\end{array}$ & $\begin{array}{l}\text { CS length } \\
\text { PP }\end{array}$ & $\begin{array}{l}\text { CS width } \\
\text { PP }\end{array}$ \\
\hline $\begin{array}{l}\text { MHNG-PLAT } 40225 \\
\text { (Type material) }\end{array}$ & $\begin{array}{l}\text { Progne } \\
\text { 'purpurea' }\end{array}$ & Brazil & $\begin{array}{l}650-740 \\
(695) \\
n=2\end{array}$ & $\begin{array}{c}295-385 \\
(350 \pm 30) \\
\mathrm{n}=8\end{array}$ & - & $\begin{array}{c}14-23 \% \\
(17 \pm 3 \%) \\
\mathrm{n}=8\end{array}$ & $\begin{array}{c}73-118 \\
(90 \pm 15) \\
n=8\end{array}$ & $\begin{array}{c}23-35 \\
(27 \pm 4) \\
n=8\end{array}$ & $\begin{array}{c}83-153 \\
(103 \pm 22) \\
\mathrm{n}=8\end{array}$ & $\begin{array}{c}25-30 \\
(28 \pm 2) \\
n=8\end{array}$ \\
\hline $\begin{array}{l}\text { MHNG-PLAT } 40266 \\
\text { (Type material) }\end{array}$ & $\begin{array}{l}\text { Progne } \\
\text { tapera } \\
\text { (Linnaeus) }\end{array}$ & Brazil & $\begin{array}{c}710 \\
\mathrm{n}=1\end{array}$ & $\begin{array}{c}310-330 \\
(320 \pm 9) \\
n=4\end{array}$ & - & $\begin{array}{c}15-16 \% \\
(15 \%) \\
n=2\end{array}$ & $\begin{array}{c}95-108 \\
(102 \pm 6) \\
n=6\end{array}$ & $\begin{array}{c}28-33 \\
(31 \pm 2) \\
n=6\end{array}$ & $\begin{array}{c}90-108 \\
(98 \pm 9) \\
n=3\end{array}$ & $\begin{array}{c}28-30 \\
(29 \pm 1) \\
n=3)\end{array}$ \\
\hline $\begin{array}{l}\text { MHNG-PLAT } 40229 \\
\text { (Type material) }\end{array}$ & Hirundo sp. & Brazil & $\begin{array}{c}660-790 \\
n=2\end{array}$ & $\begin{array}{c}240-415 \\
(319 \pm 83) \\
\mathrm{n}=8\end{array}$ & $\begin{array}{c}6-9 *(8 \pm 1) \\
{[6(5 \%), 7} \\
(46 \%), 8(30 \%), \\
9(19 \%)]\end{array}$ & $\begin{array}{c}11-19 \% \\
(13 \pm 3 \%) \\
\mathrm{n}=8\end{array}$ & $\begin{array}{c}60-93 \\
(79 \pm 11) \\
n=8\end{array}$ & $\begin{array}{c}20-28 \\
(26 \pm 3) \\
n=8\end{array}$ & $\begin{array}{c}78-88 \\
(82 \pm 4) \\
n=5\end{array}$ & $\begin{array}{c}28-30 \\
(29 \pm 1) \\
n=5\end{array}$ \\
\hline $\begin{array}{l}\text { MHNG-PLAT } 40577 \\
\text { (Type material) }\end{array}$ & Hirondella sp. & Brazil & $\begin{array}{c}700-720 \\
n=2\end{array}$ & $\begin{array}{c}255-310 \\
(293 \pm 18) \\
\mathrm{n}=8\end{array}$ & $\begin{array}{c}7-10 * *(9 \pm 1) \\
{[7(7 \%), 8} \\
(29 \%), 9(43 \%), \\
10(21 \%)]\end{array}$ & $\begin{array}{c}13-16 \% \\
(14 \pm 2 \%) \\
n=4\end{array}$ & - & - & $\begin{array}{c}68-73 \\
(70 \pm 2) \\
n=4\end{array}$ & $\begin{array}{c}18-23 \\
(22 \pm 3) \\
n=4\end{array}$ \\
\hline $\begin{array}{l}\text { MHNG-PLAT } 40227 \text {, } \\
\text { MHNG-PLAT } 39528 \text {, } \\
\text { MHNG-PLAT } 39529 \text {, } \\
\text { MHNG-PLAT } 39519\end{array}$ & $\begin{array}{l}\text { Progne } \\
\text { chalybea } \\
\text { (Cabanis) }\end{array}$ & Paraguay & $\begin{array}{c}760-975 \\
(858 \pm 73) \\
n=9\end{array}$ & $\begin{array}{c}290-360 \\
(326 \pm 17) \\
n=34\end{array}$ & $\begin{array}{c}5-8 * * *(7 \pm 1) \\
{[5(2 \%), 6} \\
(19 \%), 7(48 \%) \\
8(31 \%)]\end{array}$ & - & - & - & $\begin{array}{c}72-125 \\
(102 \pm 6) \\
n=16\end{array}$ & $\begin{array}{c}21-30 \\
(27 \pm 3) \\
n=16\end{array}$ \\
\hline $\begin{array}{l}\text { MHNG-PLAT } 39522, \\
\text { MHNG-PLAT } 39523\end{array}$ & $\begin{array}{l}\text { Stelgidopteryx } \\
\text { ruficollis } \\
\text { (Viellot) }\end{array}$ & Paraguay & $\begin{array}{c}840-1000 \\
(900 \pm 47) \\
n=9\end{array}$ & $\begin{array}{c}305-460 \\
(361 \pm 43) \\
n=36\end{array}$ & $\begin{array}{c}5-7^{a}(6 \pm 1) \\
{[5(20 \%), 6} \\
(50 \%), 7(30 \%)]\end{array}$ & - & - & - & - & - \\
\hline MHNG-PLAT 83087 & $\begin{array}{l}\text { Tachycineta } \\
\text { meyeni } \\
\text { (Cabanis) }\end{array}$ & Chile & $\begin{array}{c}670-900 \\
(748 \pm 97) \\
\mathrm{n}=5\end{array}$ & $\begin{array}{c}305-410 \\
(357 \pm 32) \\
n=12\end{array}$ & $5-7^{b}(6 \pm 1)$ & - & - & - & - & - \\
\hline
\end{tabular}

$\mathrm{CS}$ - cirrus sac; MP - mature proglottides; $\mathrm{PP}$ - pregravid proglottides; ${ }^{*} \mathrm{n}=37 ; *^{*} \mathrm{n}=14 ; * * * \mathrm{n}=54 ;{ }^{\mathrm{a}} \mathrm{n}=10 ;{ }^{\mathrm{b}} \mathrm{n}=3$.

characterised by a scolex $650-994 \mu \mathrm{m}$ in diameter, a cirrus sac $60-178 \mu \mathrm{m}$ in length in mature proglottides, and a paruterine organ that turns inward and expands towards the uterus rather than protruding from it.

Anonchotaenia macrocephala was originally described from Progne 'purpurea', P. tapera, P. chalybea, Hirundo sp., and Hirondella sp. Of the syntypes available at the MHNG, the most intact specimens are from Progne 'purpurea' (MHNG-PLAT-40226); this host species name seems to be the latinisation of the common name purple martin (Progne subis). Voucher material from T. leucorrhoa, T. meyeni, and $S$. ruficollis represent new host genera and species records for A. macrocephala and extend the geographic distribution of the species beyond Brazil to include areas in Paraguay and Chile.

\section{Molecular analysis}

The combined molecular dataset included a total of 6328 aligned characters (ssrDNA: 2692 characters, lsrDNA: 2119 characters, rrnL: 917 characters, coxl: 600 characters).

Pairwise uncorrected p-distances between the cox 1 gene fragments were as follows: between specimens of A. prolixa (PBI-147) and those identified as A. brasiliensis (PBI-204+212) averaged 14.3\% $\pm 0.6 \%$; between A. brasiliensis (PBI-204+212) and A. macrocephala (PBI$156+235)$ averaged $13.5 \% \pm 0.4 \%$; and between $A$. brasiliensis (PBI-204+212) and A. cf. brasiliensis (PBI-228) averaged $11.7 \%$. The pairwise distances between the $r r n L$ gene fragments were as follows: between specimens identified as $A$. brasiliensis (PBI-204+212) and A. prolixa (PBI-147) averaged $21.6 \% \pm 0.7 \%$; between $A$. macro- cephala (PBI-156+235) and A. prolixa (PBI-147) averaged 22.2\%; between $A$. brasiliensis (PBI-204+212) and A. macrocephala (PBI-156+235) averaged 18.9\% $\pm 0.8 \%$; and between $A$. brasiliensis (PBI-204+212) and $A$. cf. brasiliensis (PBI-228) averaged 15.6\% (Table 5).

The log-likelihood of the topology produced by the ML analysis of the combined dataset was -14462.43 . The harmonic means of estimated marginal likelihood values from the two BI runs were -14107.63 and -14113.62 . The topologies of the BI and ML analyses were identical, thus only the results from the BI analysis are shown; all nodes were supported by $\mathrm{pp} \geq 0.99$ (Fig. 11). Anonchotaenia prolixa (PBI-147) placed basal to other representatives of Anonchotaenia. Specimens of A. macrocephala (PBI156 and PBI-235) formed a clade distinct from specimens of A. brasiliensis. Anonchotaenia brasiliensis (PBI-204) was more closely related to $A$. brasiliensis (PBI-212) than to $A$. cf. brasiliensis (PBI-228). The long branch-length separating $A$. cf. brasiliensis (PBI-228) from A. brasiliensis (PBI-204+212) and the comparatively large pairwise genetic distance between them $(11.7 \%$ cox $1,19.0 \% \mathrm{rrnL}$; see above) suggests these to be separate species.

\section{Host specificity}

The host data for each paruterinid used in the assessment of host specificity was derived from type and voucher specimens. The $\mathrm{HS}_{\mathrm{S}}$ values calculated for each cestode species and the results of the determinations of relative host specificity for each species are provided in Table 6 . The four species of paruterinids examined in this study exhibit host specificity index values ranging from $\mathrm{HS}_{\mathrm{S}}=0$ (A. prolixa) to $\mathrm{HS}_{\mathrm{S}}=5.876$ (A. brasiliensis). 
Table 5. Uncorrected pairwise distances of coxl and $r r n L$ gene fragments

\begin{tabular}{|c|c|c|c|c|c|c|c|c|c|}
\hline & $\operatorname{cox} 1$ & 1 & 2 & 3 & 4 & 5 & 6 & 7 & 8 \\
\hline 1. & A. brasiliensis (PBI-204) & & & & & & & & \\
\hline 2. & A. brasiliensis (PBI-212) & 0.009 & & & & & & & \\
\hline 3. & A. cf. brasiliensis (PBI-228) & 0.118 & 0.116 & & & & & & \\
\hline 4. & A. macrocephala (PBI-156) & 0.139 & 0.138 & 0.129 & & & & & \\
\hline 5. & A. macrocephala (PBI-235) & 0.133 & 0.131 & 0.128 & 0.011 & & & & \\
\hline 6. & A. prolixa sp. n. (PBI-147) & 0.148 & 0.148 & 0.134 & 0.141 & 0.139 & & & \\
\hline 7. & Biuterina sp. (PBI-96) outgroup & 0.154 & 0.151 & 0.158 & 0.143 & 0.138 & 0.136 & & \\
\hline \multirow[t]{2}{*}{8.} & Dictyterina cholodkowskii (PBI-173) outgroup & 0.154 & 0.155 & 0.134 & 0.139 & 0.139 & 0.144 & 0.123 & \\
\hline & $r r n L$ & 1 & 2 & 3 & 4 & 5 & 6 & 7 & 8 \\
\hline 1. & A. brasiliensis (PBI-204) & & & & & & & & \\
\hline 2. & A. brasiliensis (PBI-212) & 0.008 & & & & & & & \\
\hline 3. & A. cf. brasiliensis (PBI-228) & 0.160 & 0.152 & & & & & & \\
\hline 4. & A. macrocephala (PBI-156) & 0.194 & 0.179 & 0.189 & & & & & \\
\hline 5. & A. macrocephala (PBI-235) & 0.196 & 0.185 & 0.187 & 0.01 & & & & \\
\hline 6. & A. prolixa sp. n. (PBI-147) & 0.211 & 0.21 & 0.226 & 0.22 & 0.223 & & & \\
\hline 7. & Biuterina sp. (PBI-96) outgroup & 0.239 & 0.239 & 0.257 & 0.263 & 0.264 & 0.275 & & \\
\hline 8. & Dictyterina cholodkowskii (PBI-173) outgroup & 0.212 & 0.255 & 0.27 .8 & 0.288 & 0.289 & 0.193 & 0.243 & \\
\hline
\end{tabular}

Table 6. Host specificity data for Anonchotaenia spp. from South America.

\begin{tabular}{|c|c|c|c|c|c|c|c|c|}
\hline Cestode species & $\begin{array}{l}\text { No. host } \\
\text { species }\end{array}$ & $\begin{array}{l}\text { No. host } \\
\text { genera }\end{array}$ & $\begin{array}{l}\text { No. host } \\
\text { families }\end{array}$ & $\begin{array}{l}\text { No. host } \\
\text { orders }\end{array}$ & $\begin{array}{l}\text { No. host } \\
\text { classes }\end{array}$ & Rank & $\begin{array}{l}\mathrm{HS}_{\mathrm{S}} \text { Index } \\
\text { Value }\end{array}$ & $\begin{array}{l}\text { Host specificity category } \\
\text { (Caira et al. 2003) }\end{array}$ \\
\hline Anonchotaenia prolixa sp. $\mathrm{n}$. & 1 & 1 & 1 & 1 & 1 & 1 & 0 & oioxenous \\
\hline Anonchotaenia vaslata sp. $\mathrm{n}$. & 2 & 2 & 1 & 1 & 1 & 1,001 & 3.000 & metastenoxenous \\
\hline Anonchotaenia macrocephala & 6 & 3 & 1 & 1 & 1 & 2,003 & 3.302 & metastenoxenous \\
\hline Anonchotaenia brasiliensis & 6 & 5 & 3 & 1 & 1 & 75,1497 & 5.876 & euryxenous \\
\hline
\end{tabular}

\section{DISCUSSION}

\section{Morphology}

Morphological distinction amongst Anonchotaenia species can be challenging due to the scarcity of morphological characters and their tendency to become easily obscured or distorted in contracted material. In this study, we complement the set of historically useful characters for species delimitation with some previously disregarded additional characters. Paruterine organ shape is easily distorted by contraction in short proglottides and has not been considered reliable for species delimitation within Anonchotaenia (Fuhrmann 1908, Joyeux and Baer 1935, Rausch and Morgan 1947), although this character has been informative of species boundaries for other paruterinid genera (Georgiev and Kornyushin 1994).

Contrary to expectation, paruterine organ shape was distinguishable and remarkably consistent within each of the four Anonchotaenia spp. examined here (Figs. 3D,E, 4D,E, 5D-F, 7A, 8C,E,F, 10B,C). Anonchotaenia brasiliensis and A. prolixa had paruterine organs with a similar shape, a conical paruterine organ that maintained this shape in pregravid proglottides. Anonchotaenia macrocephala had a paruterine organ that was initially conical but in pregravid proglottides pressed posteriorly towards the anterior uterine wall forming a conical pocket inside the anterior margin of the uterus although not invading it. Anonchotaenia vaslata had a paruterine organ that was initially conical but curved dorsally in pregravid proglottides. These differences were present in contracted and relaxed proglottides, suggesting that these differences were not an artefact of proglottis contraction, but rather represent species-level variation.

Among the species of Anonchotaenia examined here, landmarks of maturation of proglottides along the length of the strobila were observed and compared. The development of mature proglottides, the appearance of the paruterine organ, and the appearance of vermiform oncospheres occurred at a similar distance or number of proglottides posterior to the scolex with the number of proglottides between landmarks increasing with the length of the worm (Figs. 1, 4). Previous reports have suggested that the proglottides of some Anonchotaenia species mature earlier in the strobila than other paruterinid genera (Furhmann 1908, Rausch and Morgan 1947, Saxena and Baugh 1978), but few studies have reported variation in proglottis maturation along the length of the strobila among paruterinids. Future examination across the other 21 paruterinid genera will determine the variability of the location of these landmarks in comparison to Anonchotaenia.

Scanning electron microscopy is a standard tool used in species descriptions across a wide array of cestode taxa (see Chervy 2009) and until now has not been used to view 


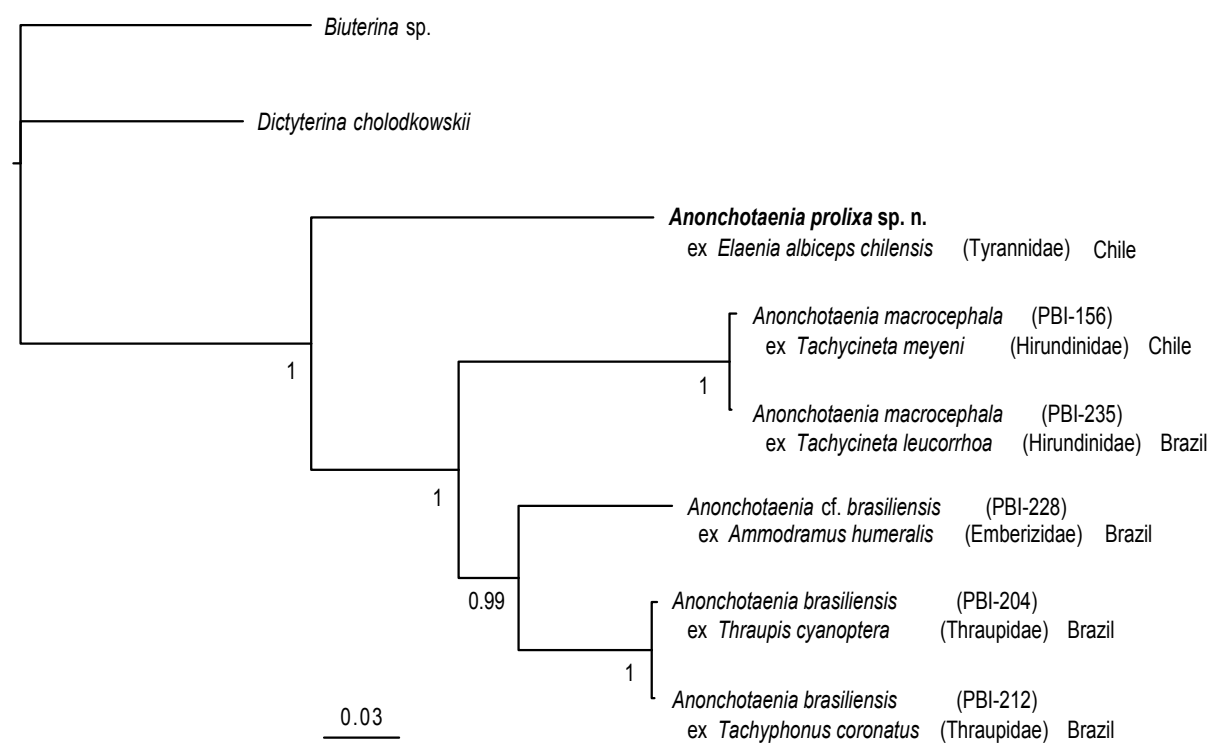

Fig. 11. Bayesian inference of the concatenated four-gene dataset depicting the phylogeny of species of Anonchotaenia. The tree was constructed using MrBayes v. 3.2.1 under the GTR+I ( $\operatorname{sr} D N A$, $l s r D N A)$ and GTR $+\mathrm{G}(r r n L, c o x l)$ models; 5 million generations, 500000 generations burn-in. The branch length scale indicates number of substitutions per site. Posterior probabilities are shown at nodes.

members of Paruterinidae. Within Cyclophyllidea, SEM has been used mostly to view scolex microthrix patterns of taxa that bear a rostellum, such as species of Dilepididae, Davaineidae, Hymenolepididae, Taeniidae and Anoplocephalidae (e.g. Mariaux and Vaucher 1990, Casado et al. 1994, Cielecka et al. 1994, Bâ et al. 1995). Our examination of scoleces of $A$. brasiliensis and A. macrocephala showed a consistent pattern of acicular filitriches across all scolex surfaces of each of the two species (Fig. 6). This is considerably less variation than has been reported for other cyclophyllidean taxa. It will be interesting to compare microthrix patterns across a broader spectrum of paruterinid taxa including both those with and without a rostellum to determine its utility as a taxonomic character among paruterinids.

\section{Molecular analysis}

This study provides the first published DNA sequence data of paruterinids beyond $\operatorname{ss} D N A$ sequences of Lyuterina nigropunctata (Spasskaya et Spasskii, 1971) (AJ555173, AJ555174, Foronda et al. 2004) and a single translated coxl sequence of A. globata (JX310719) by presenting a four-gene phylogenetic analysis of six newly sampled paruterinid species (Fig. 11). Within the clade of Anonchotaenia representatives, specimens of A. macrocephala form a clade distinct from those identified as A. brasiliensis and A. cf. brasiliensis. The distinction of these species is further supported by the greater average genetic distance between these morphologically distinct species (on average $13.5 \% \pm 0.4 \%$; Table 5) than the genetic distances between conspecifics $(0.9 \%$ in $\mathrm{A}$. brasiliensis and $0.11 \%$ in A. macrocephala; Table 5).
Of the specimens identified as A. brasiliensis, those found in tanagers (PBI-204 and PBI-212) are each other's closest relatives showing little genetic divergence (0.8-0.9\%; Table 5), whereas A. cf. brasiliensis (PBI228) from an American sparrow represents a distinct lineage to the former (Fig. 11) despite being morphologically indistinguishable. The pairwise distances between A. brasiliensis (PBI-204 + PBI-212) and A. cf. brasiliensis (PBI-228) are 13 times (coxl) and 19 times $(r r n L)$ as large as the distance between $A$. brasiliensis conspecifics (Table 5) indicating that $A$. cf. brasiliensis (PBI-228) may represent a distinct species. More specimens of $A$. cf. brasiliensis are necessary to determine if these specimens represent a cryptic species of Anonchotaenia.

Our analyses did not contradict the erection of A. prolixa as a new species. Interspecific genetic distances between previously described Anonchotaenia species (A. brasiliensis and A. macrocephala) were similar to those between these species and A. prolixa (Table 5). The inclusion of additional sequences of the other 26 Anonchotaenia spp. is needed to determine their relationship to A. prolixa.

\section{Host associations}

Members of Tyrannidae (tyrant flycatchers) are interesting hosts for Anonchotaenia species not only in terms of the diversity of tyrannids, but also because multiple Anonchotaenia species can parasitise a single tyrannid species. In this study, we found species of Tyrannidae host a diversity of morphologically distinct forms of Anonchotaenia and at least one tyrannid species is host to more than one Anonchotaenia species; T. melancholicus 
has been reported to host both Anonchotaenia jeandorsti Dollfus, 1959 and A. vaslata. Tyrannidae is the most diverse avian family in the Western Hemisphere and contains approximately 100 genera and 430 species (Rheindt et al. 2008). This study includes cestode specimens from only three species of three tyrannid genera, a minute proportion of the described diversity within the family of which most species have yet to be examined for cestodes. Concentrating efforts on examining the diversity of tyrannids for cestodes and tracking cestode presence and absence among that diversity will contribute towards understanding the breadth of tyrannid species that host Anonchotaenia, but also the frequency by which the host spectrum of different Anonchotaenia species overlaps.

Even though patterns of paruterinid host associations are poorly understood, these associations appear to be closely tied to host diet. Intermediate hosts are unknown for most paruterinid species, but are suspected to be terrestrial insects in most cases. Anonchotaenia brasiliensis has been reported from three unrelated host families (Icteridae, Fringillidae and Thraupidae) whose members consume insects in addition to fruits and seeds, and frequently participate in mixed-species foraging flocks in the South American Atlantic forest (Develey and Peres 2000). These foraging flocks are composed predominately of omnivores and insectivores (Dario and De Vincenzo 2011) and members of these flocks exhibit common behaviours that increase foraging efficiency, such as prey flushing (Sridhar et al. 2009), which may explain the broad spectrum of host associations exhibited by A. brasiliensis.

Anonchotaenia species have been reported from a variety of passerine families (see Table S2) and exhibit a wide spectrum of host specificity (Table 6). Anonchotaenia prolixa was found in a single host species and by definition is oioxenous $\left(\mathrm{HS}_{\mathrm{S}}=0\right)$, although this could be an artefact of low sampling. Anonchotaenia vaslata and $A$. macrocephala both have been reported in multiple genera of a single host family and were metastenoxenous $\left(\mathrm{HS}_{\mathrm{S}}=3.000\right.$ and $\mathrm{HS}_{\mathrm{S}}=3.302$, respectively). Anonchotaenia macrocephala has been found in more genera than
A. vaslata and thus had a higher index value. Anonchotaenia brasiliensis was the least host specific species evaluated here. It has been reported from multiple host families and was euryxenous $\left(\mathrm{HS}_{\mathrm{S}}=5.876\right)$. Host specificity of cestodes has been most thoroughly evaluated for species that parasitise elasmobranchs, partially because of the strict host specificity exhibited by most elasmobranch cestodes (Caira and Jensen 2001, Caira et al. 2003). Host specificity has not been formally assessed for most cyclophyllideans, which comprise over half of cestode diversity (>3500 species). In the present study, the $\mathrm{HS}_{\mathrm{S}}$ values of the non-oioxenous species ranged from 3.000-5.876 (Table 6). These taxa exhibit a more relaxed pattern of host specificity than exhibited by the cestode taxa most often evaluated in formal assessments of host specificity (i.e. elasmobranch cestodes). It is possible that additional paruterinid species parasitise multiple avian host species and genera and, in some cases, multiple host families.

Acknowledgements. We thank Fernando Marques for his help in organising fieldwork and permits for our work in Brazil and Natalia Da Mata Luchetti (both from Laboratorie Helmintologia Evolutiva - Universidad de São Paulo) for her effort in organising our fieldwork and for being a valuable member of our team. We are thankful for the ornithological expertise of Luis Fabio Silveira, Luciano Moreira Lima, Deborah Oliveira, Rafael Sobral Marcondes (all MZUSP), Guilherme Renzo Rocha Brito, Marco Aurélio Crozariol and Daniel Honorato Firme (all Museu Nacional, UFRJ). Fieldwork in Chile was possible with the support of the staff of the Huinay Scientific Field Station (HSFS), especially Günter Fösterra and Vreni Haüsserman. We thank the staff of the sequencing facility at the Natural History Museum in London for their sequencing expertise. We are thankful to Janine Caira (University of Connecticut) for her thoughtful comments and insights that greatly improved this manuscript, and to Kent Holsinger (University of Connecticut) for his assistance with the analyses of host specificity. Elizabeth Barbeau (University of Connecticut) and Freya Goetz (Smithsonian's National Museum of Natural History) provided valuable advice and assistance with the figures. This work was funded by the National Science Foundation, PBI grants 0818696 and 0818823 . This paper is publication number 87 of the HSFS.

\section{REFERENCES}

BÂ C.T., SÉne T., Marchand B. 1995: Scanning electron microscope examination of scale-like spines on the rostellum of five Davaineinae (Cestoda, Cyclophyllidea). Parasite 2: 63-67.

Caira J.N., Jensen K. 2001: An investigation of the co-evolutionary relationships between onchobothriid tapeworms and their elasmobranch hosts. Int. J. Parasitol. 31: 960-975.

Caira J.N., Jensen K., Holsinger K.E. 2003: On a new index of host specificity. In: C. Combes and J. Jourdane (Eds.), Taxonomy, Ecology, and Evolution of Metazoan Parasites. PUP, Perpignan, pp. 161-201.

Casado N., Pérez-Serrano J., Denegri G., RodríguezCaAbeiro F. 1994: Development of truncated microtriches in Echinococcus granulosus protoscolices. Parasitol. Res. 80: 355-357.
Chervy L. 2009: Unified terminology for cestode microtriches: a proposal from the International Workshops on Cestode Systematics in 2002-2008. Folia Parasitol. 56: 199-230.

Cholodkovsky N. 1906: Cestodes nouveaux ou peu connus. I. Arch. Parasitol. 10: 332-347.

Cielecka D., Grytner-Ziecina B., Chomicz L. 1994: Studies of the surface ultrastructure of Sobolevicanthus gracilis (Zeder, 1803) (Cestoda, Hymenolepididae). Acta Parasitol 39: 131-137.

Dario F.R., De Vincenzo M.C.V. 2011: Avian diversity and relative abundance in a resting forest of Sao Paulo, Brazil. Trop. Ecol. 52: 25-33.

Develey P.F., Peres C.A. 2000: Resource seasonality and the structure of mixed species bird flocks in a coastal Atlantic forest of southeastern Brazil. J. Trop. Ecol. 16: 33-53. 
Dollfus R.P.F. 1959: Cestodes et acanthocéphales d'oiseaux récoltés au Pérou par le Dr. Jean Dorst. Bull. Soc. Zool. Fr. 84: 384-395.

Foronda P., Casanova P.C., Valladares B., Martinez E., Feliu C. 2004: Molecular systematics of several cyclophyllid families (Cestoda) based on the analysis of $18 \mathrm{~S}$ ribosomal DNA gene sequences. Parasitol. Res. 93: 279-282.

Fuhrmann O. 1901: Neue Arten und Genera von Vogeltaenien. Zool. Anz. 24: 271-272.

Fuhrmann O. 1908: Das Genus Anonchotaenia und Biuterina. Zbl. Bakt II Natur. 46: 622-631.

Fuhrmann O. 1918: Cestodes d'oiseaux de la Nouvelle-Calédonie et des Iles Loyalty. Nova Caledonia Zool. 2: 399-449.

Fuhrmann O., Baer J. G. 1943: Cestodes. Bull. Soc. Neuchât. Sci .Nat. 68: 113-140.

Georgiev B.B. 1992: Invalidation of the genus Zosteropicola Johnston, 1912 (Cestoda: Paruterinidae: Anonchotaeniinae). Syst. Parasitol. 22: 39-44.

Georgiev B.B., Kornyushin V.V. 1993: Invalidation of the genus Anomaloporous Voge and Davis, 1953 (Cestoda: Paruterinidae). Syst. Parasitol. 25: 203-211.

Georgiev B.B., Kornyushin V.V. 1994: Family Paruterinidae Fuhrmann, 1908 (sensu lato) In: L.F. Khalil, A. Jones and R.A. Bray (Eds.), Keys to the Cestode Parasites of Vertebrates, CAB International, Wallingford, pp. 559-584.

Georgiev B.B., Vaucher C. 2001: Revision of the genus Parvirostrum Fuhrmann, 1908 (Cestoda: Cyclophyllidea: Paruterinidae). Syst. Parasitol. 50: 13-29.

Gill F., Donsker D. (Eds.) 2012: IOC World Bird Names (v. 3.2). World Wide Web electronic publication, www.worldbirdnames.org, 02/2013.

HuelsenbeCK J.P., Ronquist F. 2001: MrBayes: Bayesian inference of phylogenetic trees. Bioinformatics 17: 754-755.

Joyeux Ch., Baer J.G. 1935: Cestodes d'Indochine. Rev. Suisse Zool. 42: 249-273.

Катон K., Kuma K.-I., Тон H., Miyata T. 2005: MAFFT version 5: improvement in accuracy of multiple sequence alignment. Nucleic Acids Res. 33: 511-518.

VON Linstow O. 1879: Helminthologishe Untersuchungen. Jahresh Ver vaterl Natur Wütt 35: 313-342.

Maddison W.P., Maddison D.R. 2005: MacClade, Version 4.07. Sinauer Associates, Sunderland, MA.

Mariaux J. 1991: Cestodes of birds from the Ivory Coast. Species of the genus Anonchotaenia Cohn, 1990. Syst. Parasitol. 20: $109-120$.

Mariaux J., Vaucher C. 1990: A new genus of Dilepididae (Cestoda) of the yellowbill Ceuthmochares aereus (Cuculidae) from the Ivory Coast. J. Parasitol. 76: 22-26.

Olsen O.W., Haskins A.G., Braun C.E. 1978: Rhabdometra alpinensis n. sp. (Cestoda: Paruterinidae: Dilepididea) from southern white-tailed ptarmigan (Lagopus leucurus altipetens Osgood) Colorado, U.S.A., with a key to the species of Rhabdometra Cholodkowsky, 1906. Can. J. Zool. 56: 446-450.

Phillips A.J., Mariaux J., Georgiev B.B. 2012: Cucolepis cincta gen. n. et sp. n. (Cestoda: Cyclophyllidea) from the squirrel cuckoo Piaya cayana Lesson (Aves: Cuculiformes) from Paraguay. Folia Parasitol. 59: 287-294.

Posada D., Crandall K.A. 1998: MODElTEST: testing the model of DNA substitution. Bioinformatics 14: 817-818.

Rausch R., Morgan B.B. 1947: The genus Anonchotaenia (Cestoda: Dilepididae) from North American birds, with the description of a new species. Trans. Am. Microsc. Soc. 66: 203-211.

Rheindt F.E., Norman J.A., Christidis L. 2008: Phylogenetic relationships of tyrant-flycatchers (Aves: Tyrannidae), with an emphasis on the elaeniine assemblage. Mol. Phylogenet. Evol. 46: 88-101.

VAN RIPER C. III. 1991: Parasite communities in wet and dry forest subpopulations of the Hawaii common amakihi. In: J.E. Loye and M. Zuk (Eds.), Bird-parasite Interactions: Ecology, Evolution, and Behavior. Oxford University Press, Oxford and New York, pp. 140-153.

Saxena S.K., Baugh S.C. 1978: On cestodes of Passer domesticus II. Anonchotaenia and Mathevotaenia. Angew. Parasitol. 19: $85-106$

SCHмidt G.D. 1986: CRC Handbook of Tapeworm Identification. Boca Raton, CRC Press Inc., Florida, 688 pp.

Scholz T., de Chambrier A., Kuchta R., Littlewood D.T.J., Waeschendach A. 2013: Macrobothriotaenia ficta (Cestoda: Proteocephalidea), a parasite of sunbeam snake (Xenopeltis unicolor): example of convergent evolution. Zootaxa 3640: 485-499.

Sharma M.L. 1947: On a new species of the genus Rhabdometra Cholodkovski (1906), family Dilepididae (Fuhrmann, 1907), subfamily Paruterininae (Fuhrmann, 1908) from the intestine of Turodoides terricolor terricolor [sic]. Proc. Nat. Acad. Sci. India, B 17 (Part II): 67-78.

Sharma S., Mathur K.M. 1987: On a new cestode of the family Davaineidae Railliet et Herry, 1909. from red whiskered bulbul. J. Curr. Biosci. 4: 17-20.

Shinde G.B. 1984: A new species of the genus Anonchotaenia Southwell, 1930 from the Passer domesticus in Maharashtra. Riv. Parassitol. 45: 395-402.

Singal D.P. 1963. On a new cestode belonging to the genus Anonchotaenia Cohn, 1900, from the house sparrow, Passer domesticus indicus Jardine and Selby, 1835. Proc. Zool. Soc. 16: $215-218$

SinGH K.S. 1952: Cestode parasites of birds. Ind. J. Helminthol. 4: $1-72$.

SINGH K.S. 1964: On six new avian cestodes from India. Parasitology 54: 177-194.

Southwell T. 1930: Cestoda. The Fauna of British India, Including Ceylon and Burma. Taylor and Francis, London, 262 pp.

Sridhar H., Beauchamp G., Shanker K. 2009: Why do birds participate in mixed-species foraging flocks? A large-scale synthesis. Anim. Behav. 78: 337-347.

SWOFFORD D.L. 2003: PAUP*: phylogenetic analysis using parsimony (*and other methods). Sinauer, Sunderland, MA.

Ulmer M., James H. 1976: Nematotaenoides ranae gen. et sp. n. (Cyclophyllidea: Nematotaeniidae), from the leopard frog (Rana pipiens) in Iowa. Proc. Helminthol. Soc. Wash. 43: 185191.

Voge M., Davis B.S. 1953: Studies on the cestode genus Anonchotaenia (Dilepididae, Paruterininae) and related forms. Univ. Calif. Pub. Zool. 59: 1-30.

Yamaguti S. 1956: Studies on the Helminth Fauna of Japan. Part 50. Cestodes of Birds, III. Published by the author, $860 \mathrm{pp}$.

Yoneva A., Georgieva K., Mizinska Y., Nikolov P.N., GeorGiev B.B., Stoitsova S.R. 2010: Ultrastructure of spermiogenesis and mature spermatozoon of Anonchotaenia globata (von Linstow, 1879) (Cestoda, Cyclophyllidea, Paruterinidae). Acta Zool., Stockholm 91: 184-192. 